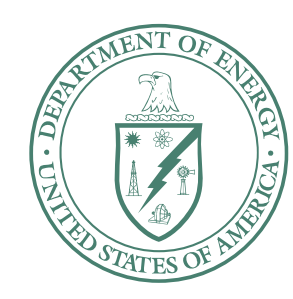

U.S. Department of Energy

Idaho Operations Office

\title{
Action Memorandum for General Decommissioning Activities under the Idaho Cleanup Project
}

October 2006 
DOE/ID-11293

Revision 0

Project No. 26574

\section{Action Memorandum for General Decommissioning Activities under the Idaho Cleanup Project}

October 2006

Prepared for the 
Signature sheet for the Action Memorandum covering general decommissioning activities at the U.S. Department of Energy's Idaho National Laboratory. This action is conducted by the U.S. Department of Energy with the concurrence of the U.S. Environmental Protection Agency and the Idaho Department of Environmental Quality.
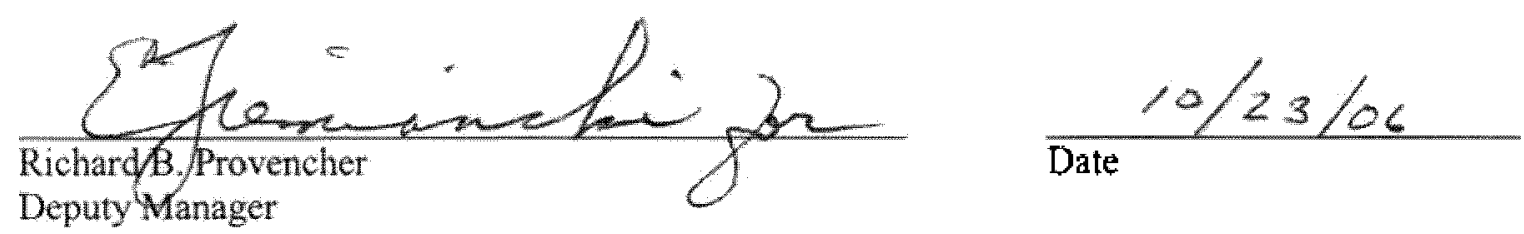

U.S. Department of Energy Idaho Operations Office 

Signature sheet for the Action Memorandum covering general decommissioning activities at the U.S. Department of Energy's Idaho National Laboratory. This action is conducted by the U.S. Department of Energy with the concurrence of the U.S. Environmental Protection Agency and the Idaho Department of Environmental Quality.

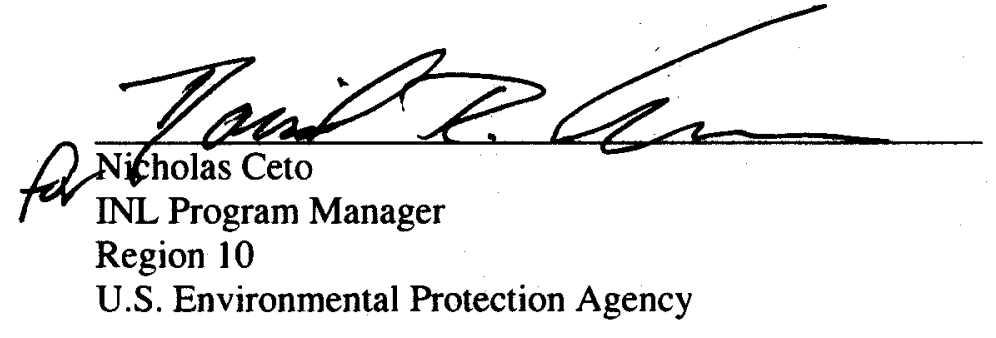

$\frac{24 \text { Oct } 06}{\text { Date }}$ 

Signature sheet for the Action Memorandum covering general decommissioning activities at the U.S. Department of Energy's Idaho National Laboratory. This action is conducted by the U.S. Department of Energy with the concurrence of the U.S. Environmental Protection Agency and the Idaho Department of Environmental Quality.
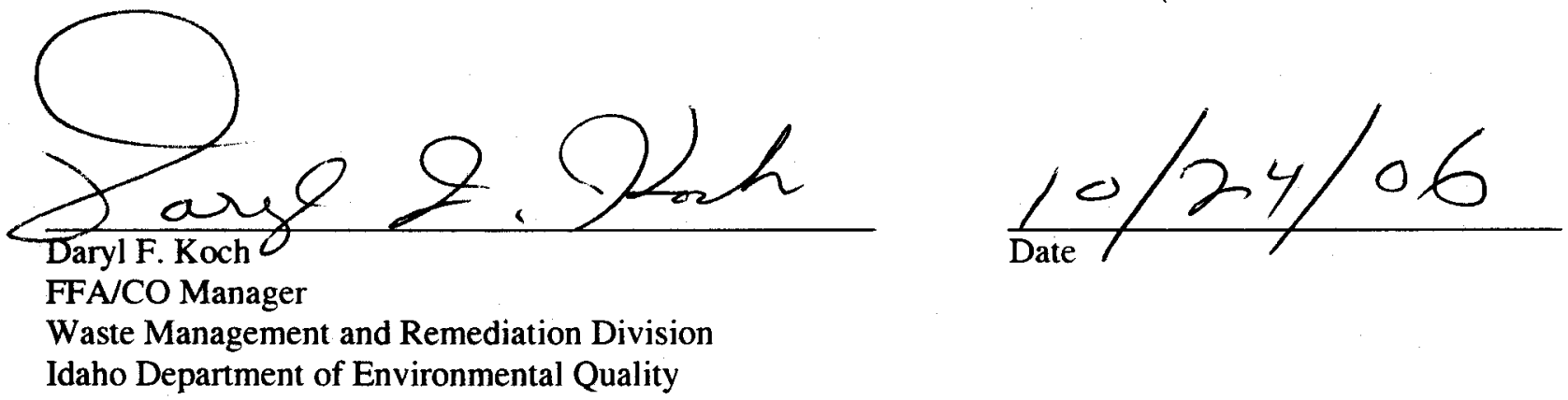

Waste Management and Remediation Division

ldaho Department of Environmental Quality 



\begin{abstract}
This Action Memorandum documents the selected alternative to perform general decommissioning activities at the Idaho National Laboratory (INL) under the Idaho Cleanup Project (ICP). Preparation of this Action Memorandum has been performed in accordance with the Comprehensive Environmental Response, Compensation, and Liability Act (CERCLA) (42 USC § 9601 et seq.), as amended by the "Superfund Amendments and Reauthorization Act of 1986" (Public Law 99-499), and in accordance with the "National Oil and Hazardous Substances Pollution Contingency Plan" (40 CFR 300). This action is consistent with the joint U.S. Department of Energy (DOE) and Environmental Protection Agency (EPA) Policy on Decommissioning of Department of Energy Facilities Under the Comprehensive Environmental Response, Compensation, and Liability Act, which establishes the CERCLA non-time-critical removal action (NTCRA) process as an approach for decommissioning. This approach satisfies environmental review requirements and provides for stakeholder involvement, while providing a framework for selecting the decommissioning alternative.

An engineering evaluation/cost analysis (EE/CA) was prepared and released for public comment and evaluated alternatives to accomplish the decommissioning of excess buildings and structures whose missions have been completed. The scope of the Action Memorandum is intended to encompass miscellaneous buildings and structures, as well as decommissioning preparatory activities for the more substantial and significant facilities that will be subsequently addressed in future NTCRAs. The selected alternative excludes the end-state decisions for these more substantial or significant facilities and decisions regarding reactor vessel disposition. Three alternatives were considered for the general decommissioning activities to be performed under the ICP: (1) No Action; (2) Removal and Disposal of Buildings, Structures, and Building Contents; and (3) Continued Surveillance and Monitoring Followed by Future Decommissioning. The selected alternative is Alternative 2.
\end{abstract}




\section{EXECUTIVE SUMMARY}

This Action Memorandum documents the selected alternative to perform general decommissioning activities at the Idaho National Laboratory (INL) under the Idaho Cleanup Project (ICP). Preparation of this Action Memorandum has been performed in accordance with the Comprehensive Environmental Response, Compensation, and Liability Act (CERCLA) (42 USC $\S 9601$ et seq.), as amended by the "Superfund Amendments and Reauthorization Act of 1986" (Public Law 99-499), and in accordance with the "National Oil and Hazardous Substances Pollution Contingency Plan" (40 CFR 300). This action is consistent with the joint U.S. Department of Energy (DOE) and Environmental Protection Agency (EPA) Policy on Decommissioning of Department of Energy Facilities Under the Comprehensive Environmental Response, Compensation, and Liability Act (DOE and EPA 1995), which establishes the CERCLA nontime-critical removal action (NTCRA) process as an approach for decommissioning. This approach satisfies environmental review requirements and provides for stakeholder involvement, while providing a framework for selecting the decommissioning alternative. An Administrative Record has been established to record information used to support the selected alternative and provide documentation of decisions and the progress of the removal action.

An engineering evaluation/cost analysis (EE/CA) was prepared and released for public comment and evaluated alternatives to accomplish the decommissioning of excess buildings and structures whose missions have been completed. Comments received during the public comment period were considered for inclusion into the Action Memorandum and are included in Appendix A, Public Comments Received during the Comment Period. The scope of the Action Memorandum is intended to encompass miscellaneous buildings and structures, as well as decommissioning preparatory activities for the more substantial and significant facilities that will be subsequently addressed in future NTCRAs. The selected alternative excludes the end-state decisions for these more substantial or significant facilities and decisions regarding reactor vessel disposition. These more substantial or significant facilities currently planned are TAN-607 Hot Shop, TRA-642 Engineering Test Reactor Vessel, TRA-603 Material Testing Reactor Vessel, PER-620 Power Burst Facility Vessel, CPP-601/640 Fuel Process Building/Headend Processing Plant, and CPP-603A Wet Fuel Storage Facility. A listing of the buildings and structures planned for decommissioning by the ICP is discussed in Section 2.1.8.

Although the general decommissioning of buildings and structures by the ICP is not specifically addressed in previous Records of Decision (RODs) at INL, this removal action is consistent with the remedial action objectives (RAOs) of previous RODs and supports the overall cleanup objectives established through the Federal Facility Agreement and Consent Order for the Idaho National Engineering Laboratory (DOE-ID 1991). Completion of the removal action will place the identified buildings and structures in a condition protective of human health and the environment. The potential contaminants of concern (COCs) that may be encountered during the decommissioning include radionuclides, asbestos, heavy metals, and organic chemicals. Completed comprehensive RODs where ICP decommissioning facilities will occur are available for Test Area North, Reactor Technology Complex, Idaho Nuclear Technology and Engineering Center, Central Facilities Area, and the Power Burst Facility. The comprehensive ROD for the Radioactive Waste Management Complex is pending. The relevant completed comprehensive Waste Area Group (WAG) RODs are

- $\quad$ Final Record of Decision for Test Area North Operable Unit 1-10, DOE/ID-10682, Rev. 0

- $\quad$ Final Record of Decision Test Reactor Area Operable Unit 2-13, DOE/ID-10586, and Explanation of Significant Differences to the Record of Decision for Test Reactor Area Operable Unit 2-13, DOE-ID-10744, Rev. 0 
- $\quad$ Final Record of Decision for the Idaho Nuclear Technology and Engineering Center, Operable Unit 3-13, DOE/ID-10660, Rev. 0

- $\quad$ Final Comprehensive Record of Decision for Central Facilities Area, Operable Unit 4-13, DOE/ID-10719, Rev. 2

- $\quad$ Record of Decision for Power Burst Facility and Auxiliary Reactor Area, Operable Unit 5-12, DOE/ID-10700.

Three alternatives were considered for the general decommissioning activities to be performed under the ICP: (1) No Action; (2) Removal and Disposal of Buildings, Structures, and Building Contents; and (3) Continued Surveillance and Monitoring Followed by Future Decommissioning. The selected removal action alternative is Alternative 2 (Removal and Disposal of Buildings, Structures, and Building Contents). When the decommissioning involves management and/or generation of wastes subject to regulation under the Idaho Hazardous Waste Management Act/Resource Conservation and Recovery Act (HWMA/RCRA), these wastes would be addressed pursuant to requirements of those regulations. The scope of the selected alternative is intended to encompass remaining miscellaneous decommissioning actions under the ICP. The scope will further include decommissioning preparatory activities (for example, isolation of utilities, chemical removal, removal of piping and equipment) for the more substantial and significant facilities that will be subsequently addressed in future NTCRAs. This Action Memorandum excludes the end-state decisions for these more substantial or significant facilities and decisions regarding reactor vessel disposition and activities already identified under existing Action Memoranda or remedial actions pursuant to the Federal Facility Agreement and Consent Order. Building contents include, but are not limited to, structural materials, pumps, pipes, tanks, boilers, compressors, ductwork, electrical components, and other equipment. The types of wastes and debris likely to require disposal include, but are not limited to, solid waste, low-level radioactive waste, asbestos waste, and polychlorinated biphenyl (PCB) -contaminated waste.

Wastes generated through implementation of the selected alternative will be dispositioned at appropriate on-Site or off-Site waste disposal facilities, in accordance with the Waste Acceptance Criteria (WAC) of those facilities. For contaminated wastes generated during the decommissioning, the Idaho CERCLA Disposal Facility (ICDF) will be the preferred disposal location for wastes meeting the ICDF WAC. Demolition of building and structures will include removal of abovegrade structures. Belowgrade structures will be removed and disposed of in the same fashion as abovegrade buildings and structures. However, if belowgrade structures (including pipes and utility systems) are not contaminated or may be decontaminated to achieve RAOs and meet release criteria, they will optionally be left in place, backfilled, and brought to grade. Backfill will consist of clean fill materials and/or inert demolition waste from the abovegrade structures. If evidence of contamination to surrounding soils is encountered, those soils exceeding the RAOs will be excavated and disposed of at an appropriate on-Site or off-Site disposal facility in accordance with the WAC of the facility. Alternatively, if the soil contamination is extensive, or unusually complex, the site may be identified by the Department of Energy Idaho Operations Office as a new site under the Federal Facility Agreement and Consent Order, with concurrence by the Idaho Department of Environmental Quality (DEQ) and EPA. 


\section{CONTENTS}

ABSTRACT iii

EXECUTIVE SUMMARY $\mathrm{V}$

ACRONYMS ix

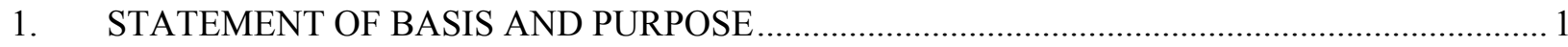

2. BACKGROUND AND FACILITY DESCRIPTIONS …........................................................ 2

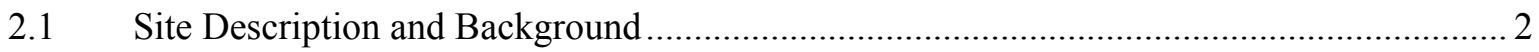

2.1.1 Idaho National Laboratory Site and Idaho Cleanup Project.............................. 2

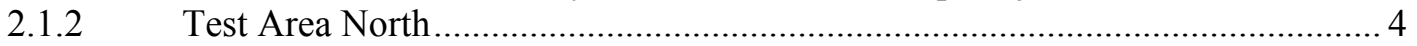

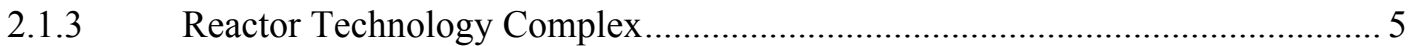

2.1.4 Idaho Nuclear Technology and Engineering Center .......................................... 5

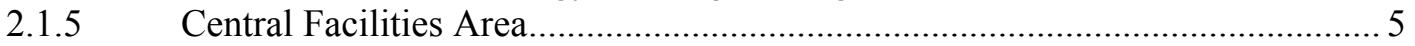

2.1.6 Power Burst Facility/Critical Infrastructure Test Range Complex ..................... 5

2.1.7 Radioactive Waste Management Complex ............................................................ 6

2.1.8 Buildings and Structures Identified for General Decommissioning.................... 6

2.2 Previous Closure/Cleanup Activities at the INL Site .................................................... 17

2.2.1 Comprehensive Environmental Response, Compensation, and Liability Act Activities at the INL Site ........................................................... 17

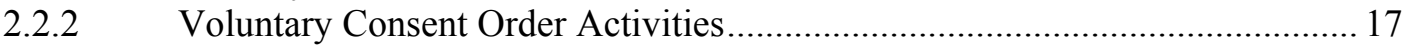

3. THREAT TO PUBLIC HEALTH, WELFARE, AND/OR THE ENVIRONMENT ...................... 17

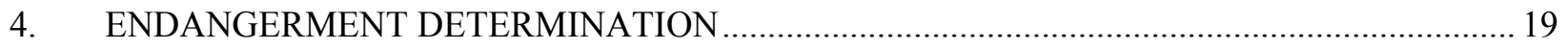

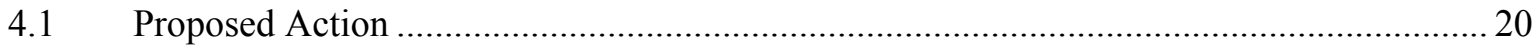

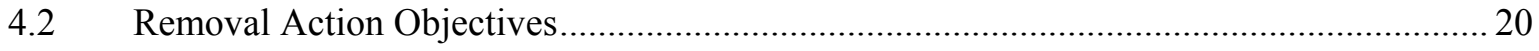

4.3 Engineering Evaluation/Cost Analysis ......................................................................... 21

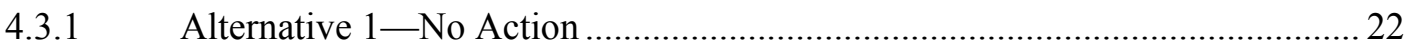

4.3.2 Alternative 2-Removal and Disposal of Buildings, Structures, and Building Contents................................................................................... 22

4.3.3 Alternative 3-Continued Surveillance and Monitoring, Followed by Future Decommissioning

4.4 Compliance with Environmental Regulations, Including Those That Are Applicable or Relevant and Appropriate Requirements

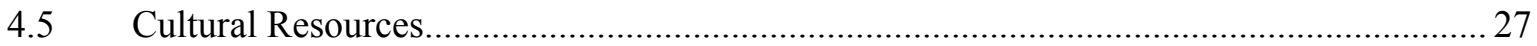

4.6 Compliance with Disposal Facility Waste Acceptance Criteria ........................................22 


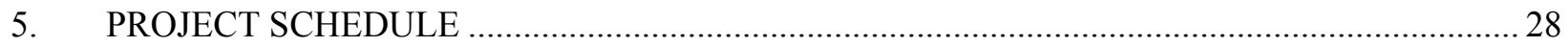

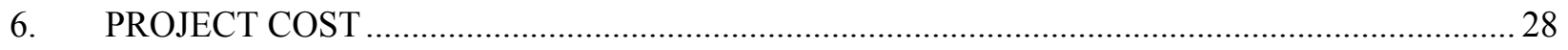

7. EXPECTED CHANGE SHOULD ACTION BE DELAYED OR NOT TAKEN.........................28

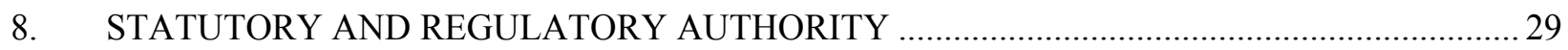

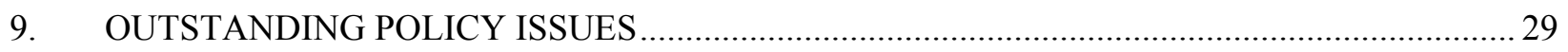

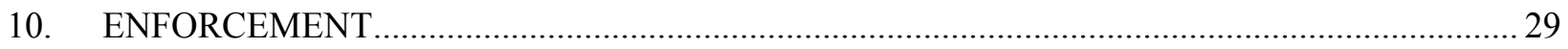

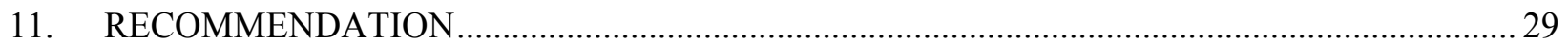

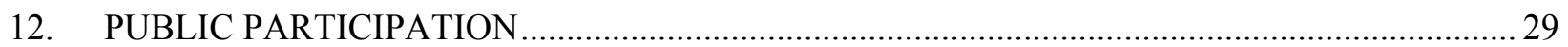

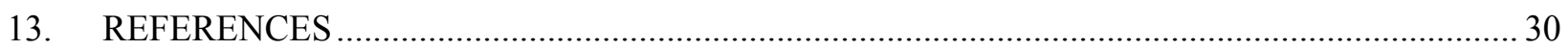

Appendix A-Public Comments Received during the Comment Period .................................................. 35

\section{FIGURES}

1. Map of the Idaho National Laboratory Site showing the location of major facilities ....................... 3

2. Area map of TAN-TSF with small facilities in yellow and major facilities in red ....................... 11

3. Area map of Reactor Technology Complex with small facilities in yellow and major

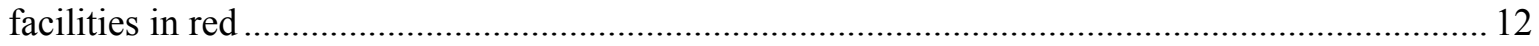

4. Area map of Idaho Nuclear Technology and Engineering Center with small facilities in

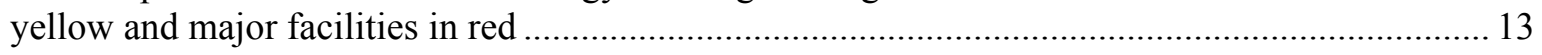

5. Area map of Radioactive Waste Management Complex with small facilities in yellow ................ 14

6. Area map of Power Burst Facility with major facilities in red................................................ 15

7. Area map of Test Area North - CTF/LOFT with small facilities in yellow ................................ 16

\section{TABLES}

1. Buildings and structures proposed for general decommissioning ............................................. 6

2. Summary of applicable or relevant and appropriate requirements for the general decommissioning non-time-critical removal action

3. Present-worth cost estimate for the selected alternative, by area 28 


\section{ACRONYMS}

ACHP Advisory Council on Historic Preservation

ARAR applicable or relevant and appropriate requirement

ATR Advanced Test Reactor

CERCLA Comprehensive Environmental Response, Compensation, and Liability Act

CFA Central Facilities Area

CFR Code of Federal Regulations

CITRC Critical Infrastructure Test Range Complex

COC contaminant of concern

CRMP Cultural Resources Management Plan

CTF Contained Test Facility

DEQ (Idaho) Department of Environmental Quality

DOE Department of Energy

DOE-ID Department of Energy Idaho Operations Office

$\mathrm{EE} / \mathrm{CA} \quad$ engineering evaluation/cost analysis

EPA Environmental Protection Agency

ETR Engineering Test Reactor

FFA/CO Federal Facility Agreement and Consent Order

HEPA high-efficiency particulate air (filter)

HWMA Hazardous Waste Management Act

ICDF Idaho CERCLA Disposal Facility

ICP Idaho Cleanup Project

IDAPA Idaho Administrative Procedures Act

INEEL Idaho National Engineering and Environmental Laboratory

INL Idaho National Laboratory

INTEC Idaho Nuclear Technology and Engineering Center 


\begin{tabular}{|c|c|}
\hline LOFT & Loss-of-Fluid Test \\
\hline MTR & Materials Testing Reactor \\
\hline NHPA & National Historic Preservation Act \\
\hline NTCRA & non-time-critical removal action \\
\hline OU & operable unit \\
\hline PBF & Power Burst Facility \\
\hline PCB & polychlorinated biphenyl \\
\hline RAO & remedial action objective/removal action objective \\
\hline RCRA & Resource Conservation and Recovery Act \\
\hline ROD & Record of Decision \\
\hline RTC & Reactor Technology Complex \\
\hline RWMC & Radioactive Waste Management Complex \\
\hline S\&M & surveillance and monitoring \\
\hline SHPO & State Historic Preservation Officer \\
\hline SMC & Specific Manufacturing Capability \\
\hline SPERT & Special Power Excursion Reactor Test \\
\hline SRPA & Snake River Plain Aquifer \\
\hline TAN & Test Area North \\
\hline $\mathrm{TBC}$ & to be considered \\
\hline TRA & Test Reactor Area \\
\hline TSF & Technical Support Facility \\
\hline USC & United States Code \\
\hline $\mathrm{VCO}$ & Voluntary Consent Order \\
\hline WAC & Waste Acceptance Criteria \\
\hline WAG & waste area group \\
\hline
\end{tabular}




\section{Action Memorandum for General Decommissioning Activities under the Idaho Cleanup Project}

\section{STATEMENT OF BASIS AND PURPOSE}

This Action Memorandum documents the selection of the recommended alternative (Alternative 2, Removal and Disposal of Buildings, Structures, and Building Contents) as identified in the Engineering Evaluation/Cost Analysis for General Decommissioning Activities under the Idaho Completion Project (DOE-ID 2006a). The Action Memorandum has been prepared in accordance with the Comprehensive Environmental Response, Compensation, and Liability Act (CERCLA) (42 USC § 9601 et seq.), as amended by the "Superfund Amendments and Reauthorization Act of 1986" (Public Law 99-499), and the "National Oil and Hazardous Substances Pollution Contingency Plan" (40 CFR 300). Although the general decommissioning of buildings and structures by the Idaho Cleanup Project (ICP) is not specifically addressed in previous Records of Decision (RODs) at the Idaho National Laboratory (INL), this removal action is consistent with the remedial action objectives (RAOs) of previous RODs and supports the overall cleanup objectives established through the Federal Facility Agreement and Consent Order for the Idaho National Engineering Laboratory (DOE-ID 1991). This action is also consistent with the joint Department of Energy (DOE) and Environmental Protection Agency (EPA) Policy on Decommissioning of Department of Energy Facilities Under the Comprehensive Environmental Response, Compensation, and Liability Act (CERCLA) (DOE and EPA 1995), which establishes the Comprehensive Environmental Response, Compensation, and Liability Act (CERCLA) non-time-critical removal action (NTCRA) process as an approach for decommissioning.

The scope of the removal action is intended to encompass demolition of miscellaneous buildings and structures, as well as decommissioning preparatory activities (for example, isolation of utilities, chemical removal, removal of piping and equipment) for the more substantial and significant facilities that will be subsequently addressed in future NTCRAs. These more substantial or significant facilities currently planned are TAN-607 Hot Shop, TRA-642 Engineering Test Reactor Vessel, TRA-603 Material Testing Reactor Vessel, PER-620 Power Burst Facility Vessel, CPP-601/640 Fuel Process Building/Headend Processing Plant, and CPP-603A Wet Fuel Storage Facility. This Action Memorandum excludes the end-state decisions for these more substantial or significant facilities and decisions regarding reactor vessel disposition and activities already identified under existing Action Memoranda or remedial actions pursuant to the Federal Facility Agreement and Consent Order (FFA/CO) (DOE-ID 1991). A listing of facilities subject to the scope of this removal action is included in Section 2.1.8.

Some buildings or structures slated for decommissioning may be found to be unsuitable for inclusion within the NTCRA or may find unforeseen future uses prior to performing the demolition. If this occurs and eliminating the facility from the list identified in Table 1 is appropriate, concurrence from the Idaho Department of Environmental Quality (DEQ) and EPA will first be obtained, and a letter will be placed in the Administrative Record for this NTCRA identifying the building or structure and explaining why it is no longer appropriate for inclusion under the scope of the NTCRA. Furthermore, ICP may be asked to decommission other INL buildings and structures with similar characteristics, contaminants, and complexity to those specifically identified in Section 2.1.8, Table 1. This Action Memorandum intends to allow the potential future inclusion of such buildings and structures under the scope of this NTCRA, as appropriate. If additional buildings and structures are added to the list in Table 1, concurrence from DEQ and EPA will first be obtained, and a letter will be placed in the Administrative Record for this NTCRA identifying the building or structure and explaining why it is sufficiently similar to the facilities 
specifically identified in this Action Memorandum and appropriate for inclusion under the scope of the NTCRA.

This NTCRA is intended to simplify administrative processes for management of wastes generated during decommissioning. The types of wastes typically generated during decommissioning include, but are not limited to, structural materials, pumps, pipes, tanks, boilers, compressors, ductwork, electrical components, and other equipment. The typical classifications of these wastes and debris likely to require disposal include, but are not limited to, solid waste, low-level radioactive waste, asbestos waste, and polychlorinated biphenyl (PCB) -contaminated waste. Wastes generated through implementation of this NTCRA will be dispositioned at appropriate on-Site or off-Site waste disposal facilities, in accordance with the Waste Acceptance Criteria (WAC) of those facilities.

The Idaho CERCLA Disposal Facility (ICDF) is the preferred disposal location for wastes meeting the ICDF WAC (DOE-ID 2006b). For wastes eligible for disposal as solid wastes, the Test Area North (TAN) Industrial Waste Landfill will be used for disposal of wastes generated near TAN, and the Central Facilities Area (CFA) Industrial Waste Landfill will be utilized for wastes generated elsewhere at the INL. When the decommissioning involves management and/or generation of wastes subject to regulation under the Idaho Hazardous Waste Management Act/Resource Conservation and Recovery Act (HWMA/RCRA), these wastes will be addressed pursuant to requirements of those regulations. If evidence of contamination to surrounding soils is encountered, those soils exceeding the remedial action objectives (RAOs) may be excavated and disposed of at an appropriate on-Site or off-Site disposal facility in accordance with the WAC of the facility. Section 4.2 further discusses the RAOs for this removal action. Alternatively, if the soil contamination is extensive, or unusually complex, the site may be identified by the Department of Energy Idaho Operations Office (DOE-ID) as a new site under the Federal Facility Agreement and Consent Order (DOE-ID 1991), with concurrence by the DEQ and EPA. If a site is included under the FFA/CO, the site would be subject to further investigation and a subsequent response action as necessary under the FFA/CO.

Performance of this removal action will place the facilities in a configuration that is protective of human health and the environment. Without decommissioning of these buildings and structures, a potential threat of release of hazardous substances exists, and, without action, adverse threats to human health and the environment eventually could occur. As the lead agency, DOE has determined that a removal action is an appropriate means to accomplish the final end state and achieve environmental review requirements. Both the DEQ and the EPA concur that a NTCRA is warranted to place these excess facilities in a configuration that is protective of human health and the environment.

\section{BACKGROUND AND FACILITY DESCRIPTIONS}

This section provides summary background information and a description of the areas at INL Site where decommissioning activities will occur. This section identifies previous and ongoing closure and cleanup activities, including a description of the buildings and structures that are addressed in this Action Memorandum and additional information relevant to the scope of this NTCRA. This section also provides a summary of the radiological and nonradiological contaminants of concern (COCs) likely to be encountered while conducting the decommissioning.

\subsection{Site Description and Background}

\subsubsection{Idaho National Laboratory Site and Idaho Cleanup Project}

The INL Site, managed by DOE, is located $51 \mathrm{~km}(32 \mathrm{mi})$ west of Idaho Falls, Idaho (Figure 1). The INL Site occupies $2,305 \mathrm{~km}^{2}\left(890 \mathrm{mi}^{2}\right)$ of the northeastern portion of the Eastern Snake River Plain. 


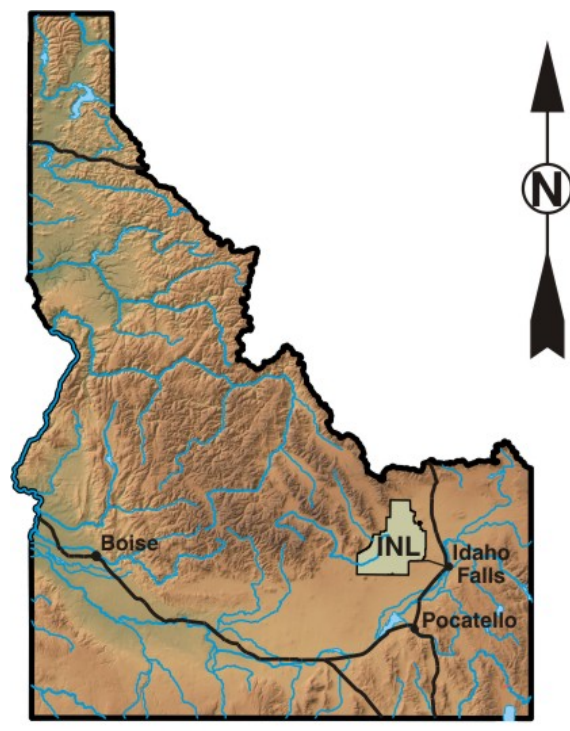

IDAHO

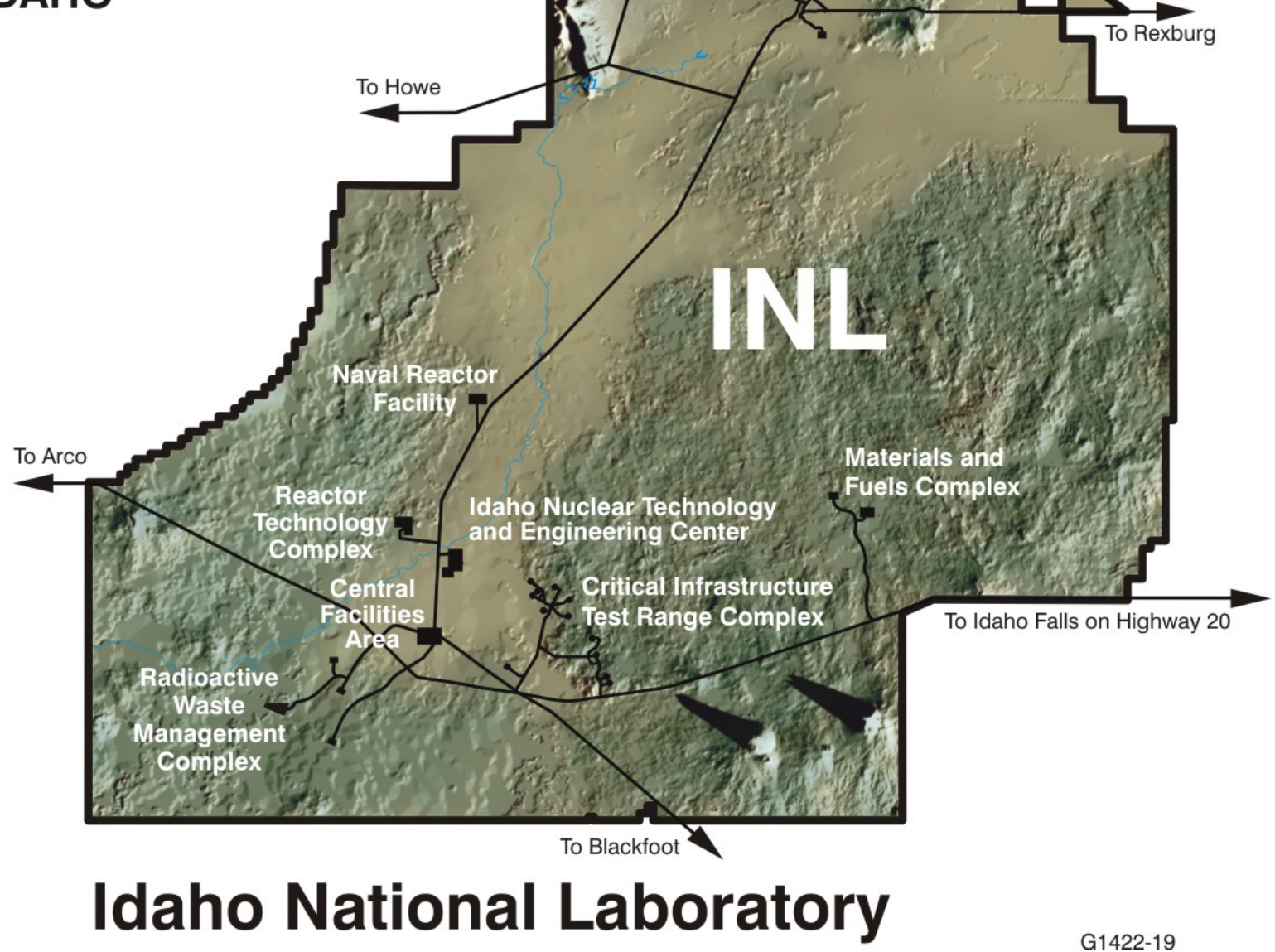

Figure 1. Map of the Idaho National Laboratory Site showing the location of major facilities. 
In 1949, the U.S. Atomic Energy Commission established the INL Site, which was called the National Reactor Testing Station at that time. Its purpose was to conduct nuclear energy research and related activities. It was redesignated the Idaho National Engineering Laboratory in 1974 and then the Idaho National Engineering and Environmental Laboratory (INEEL) in 1997. In 2005, to better focus the laboratory's missions, DOE established the ICP to bring the environmental management mission to completion and re-designated the site as the INL to better reflect the laboratory's new research directions.

DOE-ID controls all land within the INL Site. Public access is restricted to public highways, DOE-ID sponsored tours, special-use permits, and the Experimental Breeder Reactor I National Historic Landmark. In addition, DOE-ID supports the Shoshone-Bannock tribal members' need for access to areas on the INL Site for cultural and religious purposes.

The INL Site is located primarily in Butte County; however, it also occupies portions of Bingham, Bonneville, Clark, and Jefferson counties. The 2000 census indicated the following populations (in parentheses) for cities in the region: Idaho Falls $(50,730)$, Pocatello $(51,466)$, Blackfoot $(10,419)$, Arco (1,026), and Atomic City (25). Surface water flows on the INL Site consist mainly of three streams draining intermountain valleys to the north and northwest of the INL Site: (1) the Big Lost River, (2) the Little Lost River, and (3) Birch Creek. All of the channels terminate on the INL Site. Flows from Birch Creek and the Little Lost River seldom reach the INL Site because of irrigation withdrawals upstream. The Big Lost River and Birch Creek may flow onto the INL Site before the irrigation season or during high-water years, but the terminal reaches are usually dry. In those few wetter years when the Big Lost River carries water to the end of its channel, the water sinks into the ground.

The physical characteristics, climate, flora and fauna, demography, and cultural resources of the INL area are further described in the following documents:

- $\quad$ Final Record of Decision for Test Area North Operable Unit 1-10, DOE/ID-10682 (DOE-ID 1999a)

- $\quad$ Final Record of Decision Test Reactor Area Operable Unit 2-13, DOE/ID-10586 (DOE-ID 1997) and Explanation of Significant Differences to the Record of Decision for Test Reactor Area Operable Unit 2-13, DOE-ID-10744 (DOE-ID 2000a)

- $\quad$ Final Record of Decision for the Idaho Nuclear Technology and Engineering Center, Operable Unit 3-13, DOE/ID-10660 (DOE-ID 1999b)

- $\quad$ Final Comprehensive Record of Decision for Central Facilities Area, Operable Unit 4-13, DOE/ID-10719 (DOE-ID 2000b)

- $\quad$ Record of Decision for Power Burst Facility and Auxiliary Reactor Area, Operable Unit 5-12, DOE/ID-10700 (DOE-ID 2000c).

\subsubsection{Test Area North}

Located in the northern portion of the INL Site, the original mission of TAN was to support the U.S. Air Force in its efforts to create a nuclear-powered airplane, beginning in 1954. Although the Air Force project was terminated in 1961, the project and others after it resulted in the development of four subareas at TAN: the Initial Engine Test Facility (decommissioned in 2001), the Water Reactor Research Test Facility (decommissioned in 2004), the Technical Support Facility (currently undergoing decommissioning), and the Contained Test Facility (CTF). The U.S. Army selected the TAN CTF as the 
site for their Specific Manufacturing Capability (SMC) program, which continues to produce armor for combat vehicles.

\subsubsection{Reactor Technology Complex}

The Reactor Technology Complex (RTC), formerly known as the Test Reactor Area (TRA), has served to house high-neutron-flux nuclear reactors and to test the effect of irradiation upon materials, fuels, and equipment. It is located in the south-central portion of the INL Site. The complex was established in the early 1950s with the development of the Materials Testing Reactor (MTR) (which is located in the TRA-603 building). Two other major reactors followed: the Engineering Test Reactor (ETR) (which is located in the TRA-642 building) and the Advanced Test Reactor (ATR) (which is located in TRA-670). Removal of the fuel rods from MTR and ETR began soon after reactor operations ceased, in 1970 and 1981, respectively. Only the ATR is currently operational.

\subsubsection{Idaho Nuclear Technology and Engineering Center}

Situated in the south-central portion of the INL Site, the Idaho Nuclear Technology and Engineering Center (INTEC) began receiving, storing, and reprocessing nuclear materials in 1953. Historically, INTEC has been a uranium reprocessing facility for irradiated nuclear fuel from test, defense, and research reactors in the United States and other countries. After fuel dissolution and extraction, high-level liquid waste was stored in stainless-steel underground tanks in the tank farm. The high-level liquid waste was calcined, and the resultant granular solids (calcine) were stored in stainless-steel bins encased in thick concrete vaults. In 1992, DOE announced that the reprocessing component of the INTEC mission would be phased out. This decision led to the phaseout of all related processes at INTEC. Other missions have included research, storage of spent nuclear fuel, and waste management.

\subsubsection{Central Facilities Area}

Located in the south-central portion of the INL Site, CFA has been used since 1949 to house many of the support services for all of the operations at the INL Site. Functions housed at CFA include laboratories, security operations, fire protection, a medical facility, communication systems, warehouses, a cafeteria, vehicle and equipment pools, and the bus system.

\subsubsection{Power Burst Facility/Critical Infrastructure Test Range Complex}

The Power Burst Facility (PBF), designated Building PER-620, is located within the Critical Infrastructure Test Range Complex (CITRC). The complex was originally developed in the late 1950s as the Special Power Excursion Reactor Test (SPERT) area, which was comprised of four light-water reactors and a control area. The first reactor, SPERT-I, was decontaminated and decommissioned in the late 1960s and replaced by the PBF reactor in 1970. The Waste Reduction Operations Complex program subsequently took over the empty SPERT-II, -III, and -IV buildings and the PBF Control Area and used them for treatment, storage, and recycling of radioactive, hazardous, mixed, and industrial/commercial waste. Operation of the Waste Reduction Operations Complex officially terminated June 3, 2004, and the area's facilities were turned over to national security programs for new missions.

By the mid-1980s, the PBF reactor had been shut down and placed in standby condition. A NTCRA for Phase 1 decommissioning of the PBF reactor has been implemented (Action Memorandum for Phase 1 of the Decommissioning of the Power Burst Reactor Building (PER-620)

[DOE-NE-ID 2005]), but end-state decisions and vessel disposition are planned for implementation through a subsequent NTCRA. 


\subsubsection{Radioactive Waste Management Complex}

The Radioactive Waste Management Complex (RWMC) is located in the southwestern corner of the INL Site. The facility encompasses a total of 177 acres and is divided into three separate areas by function: the Subsurface Disposal Area (97 acres), the Transuranic Storage Area (58 acres), and the Administration area (22 acres). The mission of the facility from 1952 to 1970 was to manage disposal of radioactive waste. Since 1970, the mission has been to dispose of low-level waste and to store, treat, and prepare stored transuranic waste for off-Site shipment and disposal (Litus and Shea 2005). Recent construction of the Advanced Mixed Waste Treatment Project expanded the RWMC's waste management operations to include treating and preparing the $62,000 \mathrm{~m}^{3}$ of stored transuranic waste for shipment out of Idaho. An accelerated retrieval project is currently underway in the Subsurface Disposal Area to remove targeted waste (graphite, filters, Series 741 and 743 sludge, and uranium roaster oxides). This activity is being performed under a separate NTCRA.

\subsubsection{Buildings and Structures Identified for General Decommissioning}

Table 1 lists the buildings and structures currently identified for general decommissioning under this NTCRA. Figures 2 through 7 are area maps showing small facilities (in yellow) and major facilities (in red). Some of these buildings currently house offices or are utilized for equipment and materials storage. Occupants, equipment, and materials may need to be relocated prior to decommissioning. As discussed in Section 1, if new information arises during the decommissioning or the inclusion of additional facilities is deemed appropriate, the list may be modified, with DEQ and EPA concurrence, and notice placed in the Administrative Record.

Table 1. Buildings and structures proposed for general decommissioning. ${ }^{\text {a }}$

\begin{tabular}{|c|c|c|c|}
\hline $\begin{array}{l}\text { INL Site } \\
\text { Bldg. ID }\end{array}$ & Name & Major Facilities & Small Facilities \\
\hline CPP-1607 & Automatic Foam Fire Prot. Bldg & & $\mathrm{X}$ \\
\hline CPP-1619 & Haz Chem/Rad Waste Fac. & & $\mathrm{X}$ \\
\hline CPP-1634 & Technology Dev. Facility & & $\mathrm{X}$ \\
\hline CPP-1635 & Haz. Chemical Storage Facility & & $\mathrm{X}$ \\
\hline CPP-1636 & Warehouse & & $\mathrm{X}$ \\
\hline CPP-1644 & Bulk Chemical Unloading & & $\mathrm{X}$ \\
\hline CPP-1646 & Anti-C Safety Handling & & $\mathrm{X}$ \\
\hline CPP-1649 & Instrument Storage \& Maintenance Facility & & $\mathrm{X}$ \\
\hline CPP-1651 & Operations Training Facility & & $\mathrm{X}$ \\
\hline CPP-1653 & Subcontractor's Warehouse & & $\mathrm{X}$ \\
\hline CPP-1656 & Warehouse & & $\mathrm{X}$ \\
\hline CPP-1662 & Remote Insp. Engr. Facility & & $\mathrm{X}$ \\
\hline CPP-1666 & Engineering Support Office & & $\mathrm{X}$ \\
\hline CPP-1677 & Change Room & & $\mathrm{X}$ \\
\hline CPP-1678 & Contractors Lunch Room & & $\mathrm{X}$ \\
\hline CPP-1740 & Camera Tower & & $\mathrm{X}$ \\
\hline CPP-1752 & Camera Tower & & $\mathrm{X}$ \\
\hline CPP-1755 & Cesspool for VES-CFE-6013 & & $\mathrm{X}$ \\
\hline CPP-1759 & Diesel Storage Tank Basin & & $\mathrm{X}$ \\
\hline CPP-601 & Fuel Processing Building & $\mathrm{X}$ & \\
\hline
\end{tabular}


Table 1. (continued).

\begin{tabular}{|c|c|c|c|}
\hline $\begin{array}{l}\text { INL Site } \\
\text { Bldg. ID }\end{array}$ & Name & Major Facilities & Small Facilities \\
\hline CPP-603A & Wet Fuel Storage Facility & $\mathrm{X}$ & \\
\hline CPP-609 & Cold Waste Facility Office & & $\mathrm{X}$ \\
\hline CPP-618 & Tank Farm Measure/Control & & $\mathrm{X}$ \\
\hline CPР-619 & Waste Storage Controlhouse & & $\mathrm{X}$ \\
\hline CPP-621 & Chemical Storage Pumphouse & & $\mathrm{X}$ \\
\hline CPP-622 & Tank Farm Instrument House & & $\mathrm{X}$ \\
\hline CPP-623 & Tank Farm Instrument House & & $\mathrm{X}$ \\
\hline CPP-628 & Tank Farm Controlhouse & & $\mathrm{X}$ \\
\hline CPP-632 & Instrument House, Tank Farm Area & & $\mathrm{X}$ \\
\hline CPP-634 & Waste Station WM-185 & & $\mathrm{X}$ \\
\hline CPP-635 & Waste Stations WM-187-188 & & $\mathrm{X}$ \\
\hline CPP-636 & Waste Stations WM-189/-190 & & $\mathrm{X}$ \\
\hline CPP-638 & Waste Station WM-180 & & $\mathrm{X}$ \\
\hline CPP-640 & Headend Process Plant & $\mathrm{X}$ & \\
\hline CPP-645 & Office Building & & $\mathrm{X}$ \\
\hline CPP-651 & Unirradiated. Fuel Storage Facility & & $\mathrm{X}$ \\
\hline CPP-653 & Waste Handling Facility & & $\mathrm{X}$ \\
\hline СРP-654 & Receiving Warehouse/Offices & & $\mathrm{X}$ \\
\hline CPP-656 & Office Building & & $\mathrm{X}$ \\
\hline CPP-660 & Chem. \& Haz. Material Storage & & $\mathrm{X}$ \\
\hline CPP-668 & Engineering Support Offices & & $\mathrm{X}$ \\
\hline СРP-674 & $\begin{array}{l}\text { Utilities Replacement Enhancement } \\
\text { Project (UREP) Substation \#40 }\end{array}$ & & $\mathrm{X}$ \\
\hline CPP-687 & Coal-Fired Boiler House & & $\mathrm{X}$ \\
\hline CPP-688 & Coal Plant Unload Bldg & & $\mathrm{X}$ \\
\hline CPP-689 & Coal Plant Guard House & & $\mathrm{X}$ \\
\hline CPP-690 & Coal Plant Storage Bldg & & $\mathrm{X}$ \\
\hline СРР-696 & Coal Plant Offices & & $\mathrm{X}$ \\
\hline СРP-698 & $\begin{array}{l}\text { Morrison Knudsen (MK) } \\
\text { Offices/Warehouse }\end{array}$ & & $\mathrm{X}$ \\
\hline CPP-699 & Training/Prod. Office Bldg. & & $\mathrm{X}$ \\
\hline CPP-712 & Bldg. Instrument House & & $\mathrm{X}$ \\
\hline СРP-727 & $\begin{array}{l}\text { Fluorinel Dissolution Process and Fuel } \\
\text { Storage hydrogen fluoride (FAST HF) } \\
\text { Acid Storage VES-CS-169 }\end{array}$ & & $\mathrm{X}$ \\
\hline CPP-737 & Condenser Pit/HE-WM-300 & & $\mathrm{X}$ \\
\hline CPP-738 & Cooling Water Pit / HE-WM-301 & & $\mathrm{X}$ \\
\hline СРP-739 & Condenser Pit for HE-WM-302 & & $\mathrm{X}$ \\
\hline CPP-740 & Settling Basin and Dry Well & & $\mathrm{X}$ \\
\hline CPP-743 & Condenser Pit for HE-WM-387 & & $\mathrm{X}$ \\
\hline CPP-755 & Coal Storage Pad So CPP-687 & & $\mathrm{X}$ \\
\hline СРP-758 & MAH-STA-WQ-415 & & $\mathrm{X}$ \\
\hline
\end{tabular}


Table 1. (continued).

\begin{tabular}{|c|c|c|c|}
\hline $\begin{array}{l}\text { INL Site } \\
\text { Bldg. ID }\end{array}$ & Name & Major Facilities & Small Facilities \\
\hline CPP-763 & Tank Waste Vault VES-WM-191 & & $\mathrm{X}$ \\
\hline CPP-764 & SFE Hold Tank Vault & & $\mathrm{X}$ \\
\hline CPP-775 & Fuel Oil Pump Shed, Coal Fired & & $\mathrm{X}$ \\
\hline CPP-776 & Car Thaw Station, Coal-Fired & & $\mathrm{X}$ \\
\hline CPP-778 & Elec. Substation, Coal-Fired & & $\mathrm{X}$ \\
\hline CPP-787 & Stack Exhaust Tapered & & $\mathrm{X}$ \\
\hline CPP-788 & Boiler Baghouse \#1, Coal-Fired & & $\mathrm{X}$ \\
\hline CPP-789 & Boiler Baghouse \#2, Coal-Fired & & $\mathrm{X}$ \\
\hline CPP-792 & Ash Silo, Coal-Fired & & $\mathrm{X}$ \\
\hline CРP-793 & Limestone Silo, Coal-Fired & & $\mathrm{X}$ \\
\hline CPP-794 & Coal Handling Dust Collector & & $\mathrm{X}$ \\
\hline CPP-TB-5 & Unloading Station & & $\mathrm{X}$ \\
\hline CPP-TR-35 & Office Trailer & & $\mathrm{X}$ \\
\hline PER-620 & Reactor Building & $\mathrm{X}$ & \\
\hline TAN-1729 & Cask Storage Pad & & $\mathrm{X}$ \\
\hline TAN-1731 & TAN 607A Substation & & $\mathrm{X}$ \\
\hline TAN-1734 & Emergency Generator Fuel Tank & & $\mathrm{X}$ \\
\hline TAN-1735 & Emergency Generator Fuel Tank & & $X$ \\
\hline TAN-1757 & V-Tank Consolidation Yurt & & $\mathrm{X}$ \\
\hline TAN-603 & Service Bldg/Steam Plant & & $\mathrm{X}$ \\
\hline TAN-607 & Hot Shop/Manufacturing \& Assembly & $\mathrm{X}$ & \\
\hline TAN-611 & Fuel Pump House & & $\mathrm{X}$ \\
\hline TAN-623 & Sewage Pump House & & $\mathrm{X}$ \\
\hline TAN-655 & Liquid Waste Lift Station & & $\mathrm{X}$ \\
\hline TAN-668 & Heavy Equipment Cleaning & & $\mathrm{X}$ \\
\hline TAN-686 & Office Trailer & & $X$ \\
\hline TAN-704 & Boiler Fuel Tank & & $\mathrm{X}$ \\
\hline TAN-711 & Sewage Treatment Plant & & $\mathrm{X}$ \\
\hline TAN-717 & Helicopter Pad & & $\mathrm{X}$ \\
\hline TAN-722 & 1500 kVA Substation & & $\mathrm{X}$ \\
\hline TAN-727 & Covered Stairs, E. of TAN-607 & & $\mathrm{X}$ \\
\hline TAN-733 & Water Storage Tank & & $X$ \\
\hline TAN-734 & Exhaust Stack (TAN 607) & & $\mathrm{X}$ \\
\hline TAN-774 & Concrete Slab & & $\mathrm{X}$ \\
\hline TAN-778 & $\begin{array}{l}\text { Water Blowdown Tank (Technical Support } \\
\text { Facility [TSF]) }\end{array}$ & & $\mathrm{X}$ \\
\hline TAN-790 & Abnormal Waste Storage Pad & & $\mathrm{X}$ \\
\hline TAN-791 & Spent Fuel Storage Pad & & $\mathrm{X}$ \\
\hline TAN-795 & TAN Substation & & $\mathrm{X}$ \\
\hline TAN-TR-22 & TAN 603 Change House & & $\mathrm{X}$ \\
\hline TAN-TR-23 & TAN Landfill Trailer & & $\mathrm{X}$ \\
\hline
\end{tabular}


Table 1. (continued).

\begin{tabular}{|c|c|c|c|}
\hline $\begin{array}{l}\text { INL Site } \\
\text { Bldg. ID }\end{array}$ & Name & Major Facilities & Small Facilities \\
\hline TAN-TR-25 & $\begin{array}{l}\text { Loss of Fluid Test (LOFT) ICP Support } \\
\text { Facility I (West) }\end{array}$ & & $\mathrm{X}$ \\
\hline TAN-TR-26 & LOFT ICP Support Facility II (East) & & $\mathrm{X}$ \\
\hline TAN-TR-27 & TSF ICP Support Facility I (West) & & $\mathrm{X}$ \\
\hline TAN-TR-28 & TSF ICP Support Facility II (East) & & $\mathrm{X}$ \\
\hline TAN-TR-29 & $\begin{array}{l}\text { LOFT Decontamination and } \\
\text { Decommissioning (D\&D) Craft Trailer \#2 }\end{array}$ & & $\mathrm{X}$ \\
\hline TRA-603 & Material Test Reactor Bldg. & $\mathrm{X}$ & \\
\hline TRA-604 & MTR Building Wing A & & $\mathrm{X}$ \\
\hline TRA-610 & MTR Fan House & & $\mathrm{X}$ \\
\hline TRA-626 & Maintenance Storage Building & & $\mathrm{X}$ \\
\hline TRA-630 & Catch Tank Pumphouse & & $\mathrm{X}$ \\
\hline TRA-635 & Reactor Services Building & & $\mathrm{X}$ \\
\hline TRA-642 & Engineering Test Reactor Bldg. & $\mathrm{X}$ & \\
\hline TRA-643 & ETR Compressor Building & & $\mathrm{X}$ \\
\hline TRA-644 & ETR Heat Exchanger Bldg & & $\mathrm{X}$ \\
\hline TRA-648 & ETR Electrical Building & & $\mathrm{X}$ \\
\hline TRA-654 & ETR Critical Facility & & $\mathrm{X}$ \\
\hline TRA-657 & MTR Contaminated Storage and Enclosure & & $\mathrm{X}$ \\
\hline TRA-661 & Reactor Wing South Extension & & $\mathrm{X}$ \\
\hline TRA-665 & Neutron Chopper 20 Meter House & & $\mathrm{X}$ \\
\hline TRA-668 & Reactor Wing North Extension & & $\mathrm{X}$ \\
\hline TRA-705 & ETR Secondary Filter Pit & & $\mathrm{X}$ \\
\hline TRA-706 & Delay Tanks & & $\mathrm{X}$ \\
\hline TRA-709 & MTR Air Intake & & $\mathrm{X}$ \\
\hline TRA-710 & MTR Stack \& Monitoring Building & & $\mathrm{X}$ \\
\hline TRA-755 & ETR Filter Pit & & $\mathrm{X}$ \\
\hline TRA-784 & Liquid Nitrogen Tank & & $\mathrm{X}$ \\
\hline WMF-601 & Radcon Field Office & & $\mathrm{X}$ \\
\hline WMF-603 & Pumphouse & & $\mathrm{X}$ \\
\hline WMF-604 & Change House \& Lunch Room & & $\mathrm{X}$ \\
\hline WMF-605 & Well House 87 & & $\mathrm{X}$ \\
\hline WMF-609 & Heavy Equip. Storage Shed & & $\mathrm{X}$ \\
\hline WMF-611 & Operations Support Facility & & $\mathrm{X}$ \\
\hline WMF-619 & Communication Building & & $\mathrm{X}$ \\
\hline WMF-620 & Work Control Center, Trailer & & $\mathrm{X}$ \\
\hline WMF-621 & Work Control Support, Trailer & & $\mathrm{X}$ \\
\hline WMF-622 & Office Annex, Trailer & & $\mathrm{X}$ \\
\hline WMF-628 & Type II Storage Module \#1 & & $\mathrm{X}$ \\
\hline WMF-637 & Operations Control Building & & $\mathrm{X}$ \\
\hline WMF-639 & Firewater Pumphouse \#2 & & $X$ \\
\hline
\end{tabular}


Table 1. (continued).

\begin{tabular}{|c|c|c|c|}
\hline $\begin{array}{l}\text { INL Site } \\
\text { Bldg. ID }\end{array}$ & Name & Major Facilities & Small Facilities \\
\hline WMF-645 & Construction Support Trailer & & $\mathrm{X}$ \\
\hline WMF-646 & Field Support Trailer & & $\mathrm{X}$ \\
\hline WMF-648 & $\begin{array}{l}\text { Intermediate-Level Transuranic Storage } \\
\text { Facility (ILTSF), Trailer }\end{array}$ & & $\mathrm{X}$ \\
\hline WMF-653 & Office Annex \#2, Trailer & & $\mathrm{X}$ \\
\hline WMF-655 & Material Handling Facility & & $\mathrm{X}$ \\
\hline WMF-656 & Maintenance Facility & & $\mathrm{X}$ \\
\hline WMF-657 & Const Field Support, Trailer & & $\mathrm{X}$ \\
\hline WMF-658 & RWMC Office & & $\mathrm{X}$ \\
\hline WMF-661 & Hazardous Material Storage & & $\mathrm{X}$ \\
\hline WMF-671 & $\begin{array}{l}\text { Weather Enclosure Structure (Glovebox } \\
\text { Excavator Method) }\end{array}$ & & $\mathrm{X}$ \\
\hline WMF-680 & Building Trailer & & $\mathrm{X}$ \\
\hline WMF-681 & Building Trailer & & $\mathrm{X}$ \\
\hline WMF-682 & Security Mobile Office Trailer & & $\mathrm{X}$ \\
\hline WMF-708 & Sump Pit & & $\mathrm{X}$ \\
\hline WMF-709 & Water Storage Tank \#1 & & $\mathrm{X}$ \\
\hline WMF-711 & ASB-II Foundation, Floor \& Airlock & & $\mathrm{X}$ \\
\hline WMF-714 & ILTSF \#1 & & $\mathrm{X}$ \\
\hline WMF-720 & ILTSF \#2 & & $\mathrm{X}$ \\
\hline WMF-727 & Fire Water Tank & & $\mathrm{X}$ \\
\hline WMF-732 & Propane Tank N WMF-637 & & $\mathrm{X}$ \\
\hline WMF-733 & Drum Inspection Station & & $\mathrm{X}$ \\
\hline WMF-736 & Cold Test Pit & & $\mathrm{X}$ \\
\hline WMF-737 & Gasoline Tank & & $\mathrm{X}$ \\
\hline WMF-738 & Propane Tank & & $\mathrm{X}$ \\
\hline WMF-739 & Well House, Observation 88 & & $\mathrm{X}$ \\
\hline WMF-740 & Well House, Observation 89 & & $\mathrm{X}$ \\
\hline WMF-741 & Well House, Observation 90 & & $\mathrm{X}$ \\
\hline WMF-750 & Temporary Fire Riser Bldg & & $\mathrm{X}$ \\
\hline WMFB25-601 & Engineering Test Facility & & $\mathrm{X}$ \\
\hline \multicolumn{4}{|c|}{$\begin{array}{l}\text { CPP }=\text { Chemical Processing Plant (located at Idaho Nuclear Technology and Engineering Center). } \\
\text { PER }=\text { Power Excursion Reactor (located at Power Burst Facility). } \\
\text { TAN = Test Area North. } \\
\text { TRA }=\text { Test Reactor Area (located at Reactor Technology Complex). } \\
\text { WMF = Waste Management Facility (located at Radioactive Waste Management Complex). }\end{array}$} \\
\hline
\end{tabular}




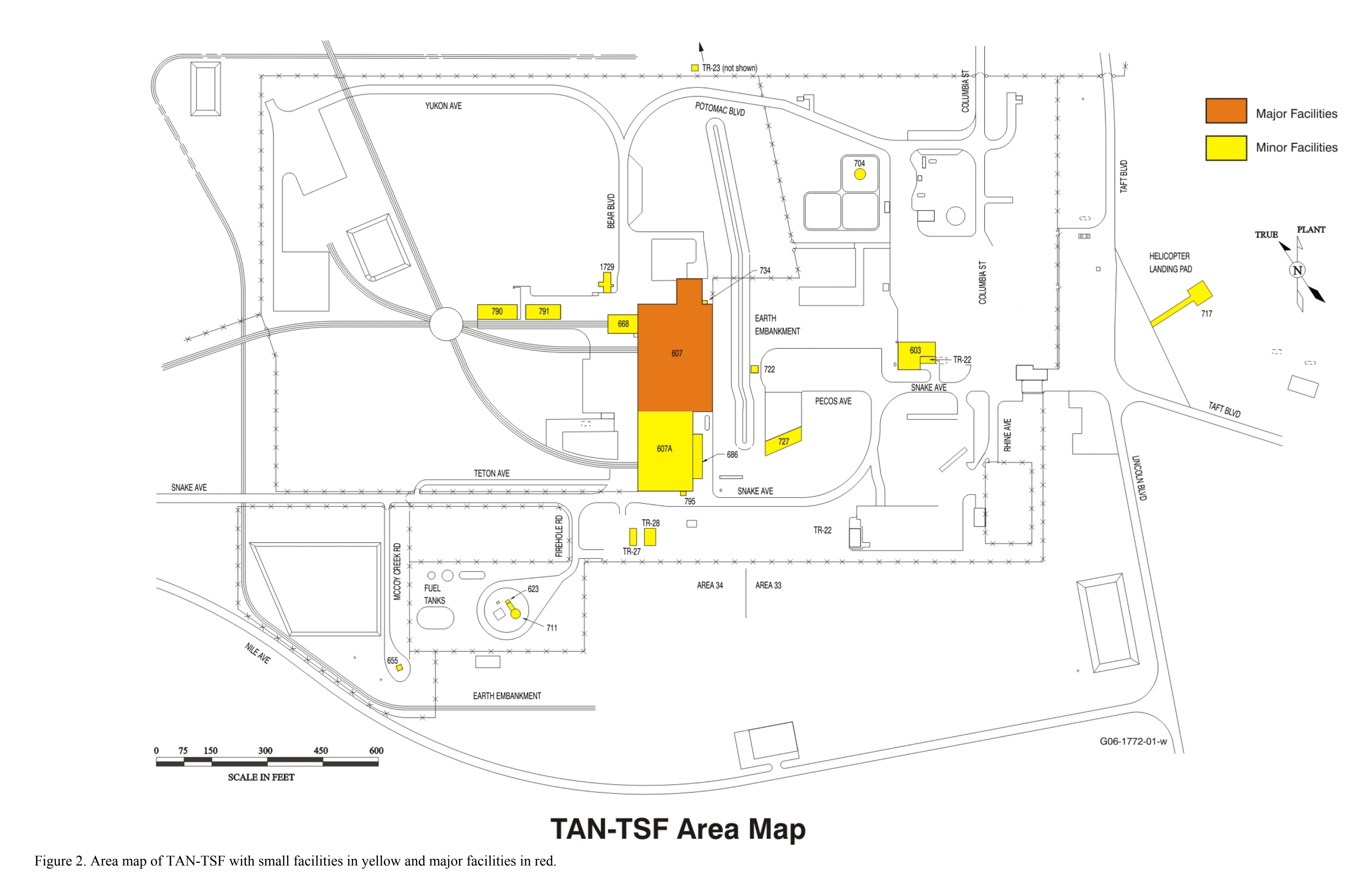




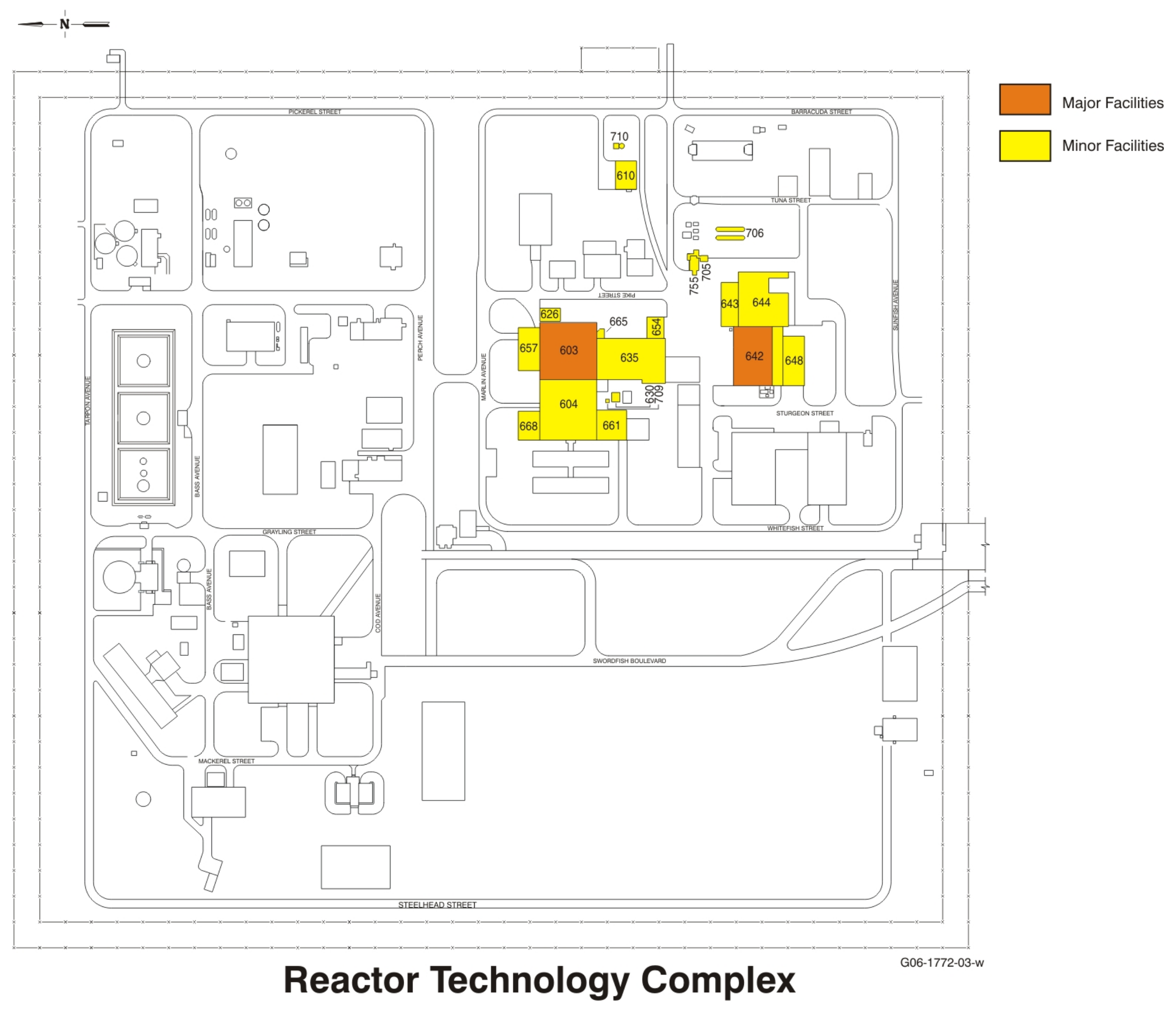

Figure 3. Area map of Reactor Technology Complex with small facilities in yellow and major facilities in red. 


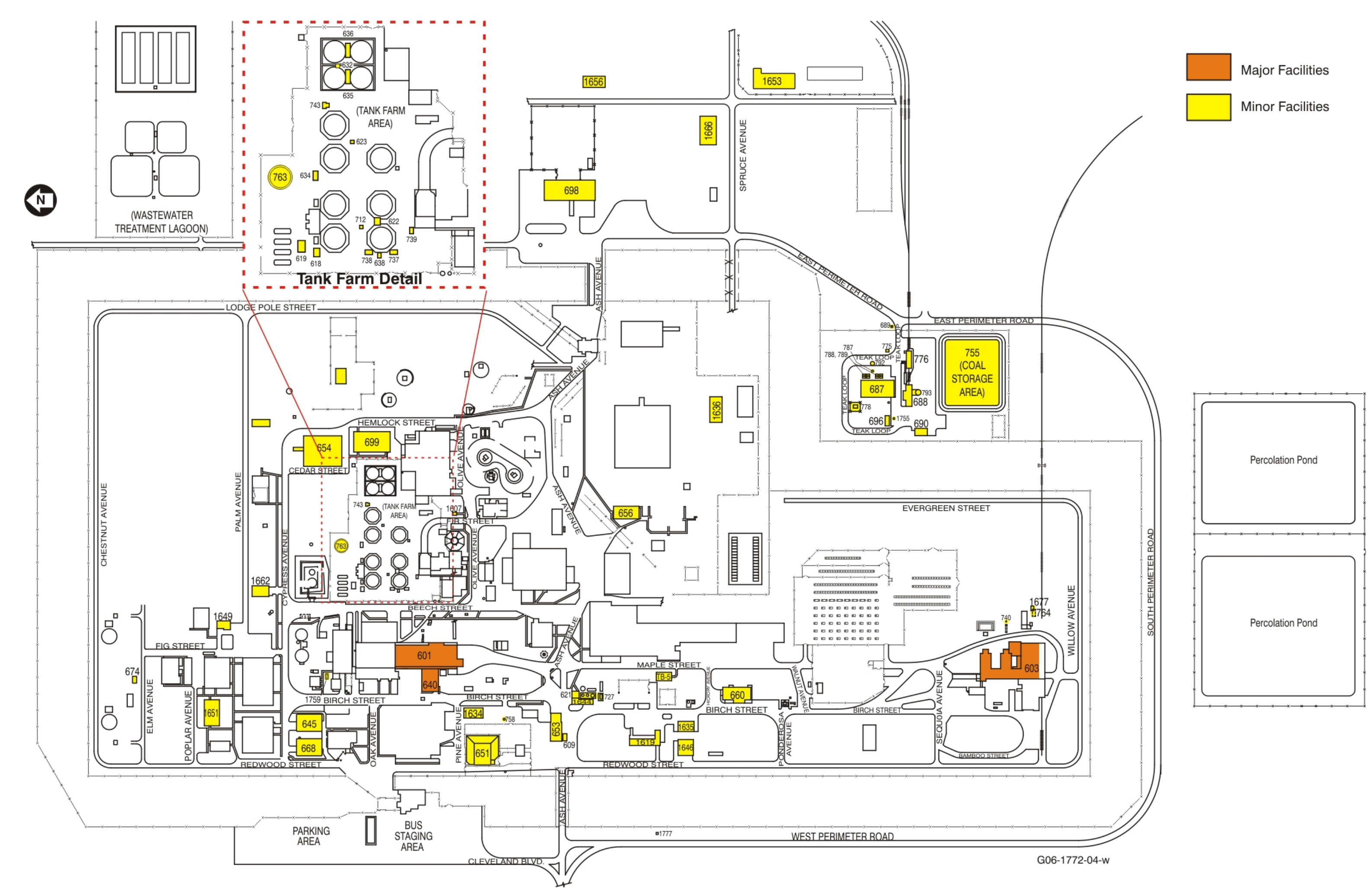

Idaho Nuclear Technology and Engineering Center

Figure 4. Area map of Idaho Nuclear Technology and Engineering Center with small facilities in yellow and major facilities in red. 


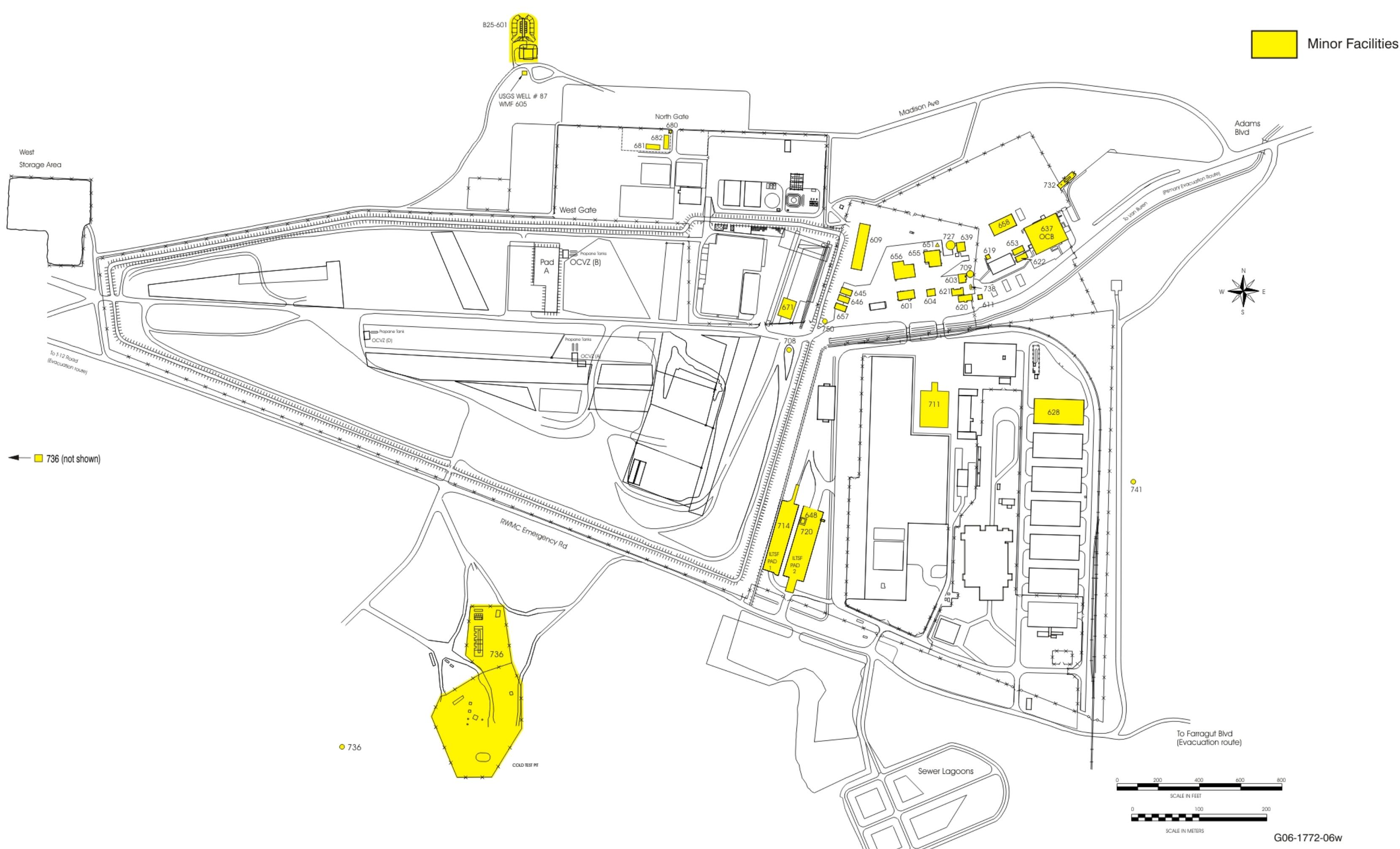

\section{Radioactive Waste Management Complex}




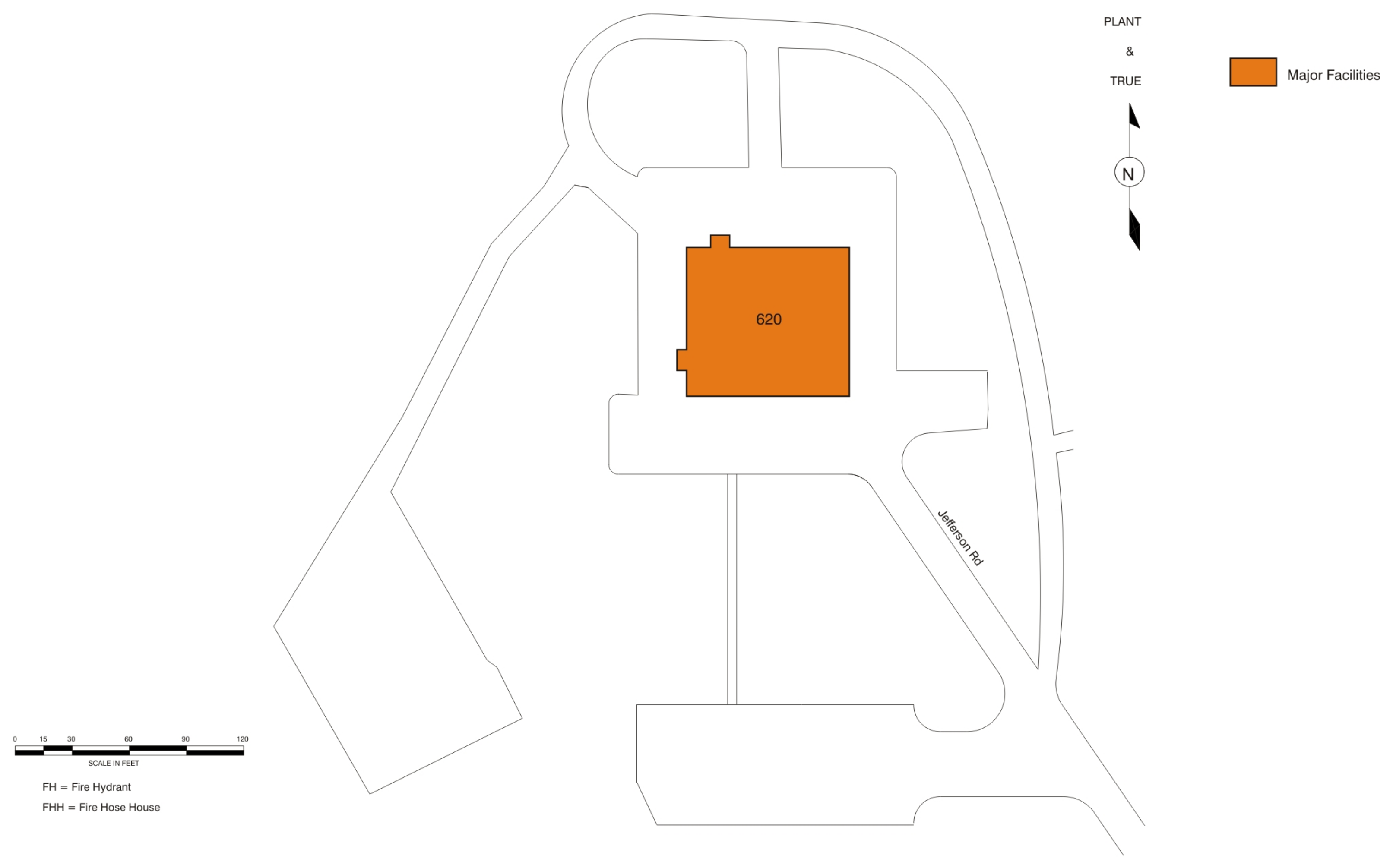

Power Burst Facility

G06-1772-07

Figure 6. Area map of Power Burst Facility with major facilities in red. 


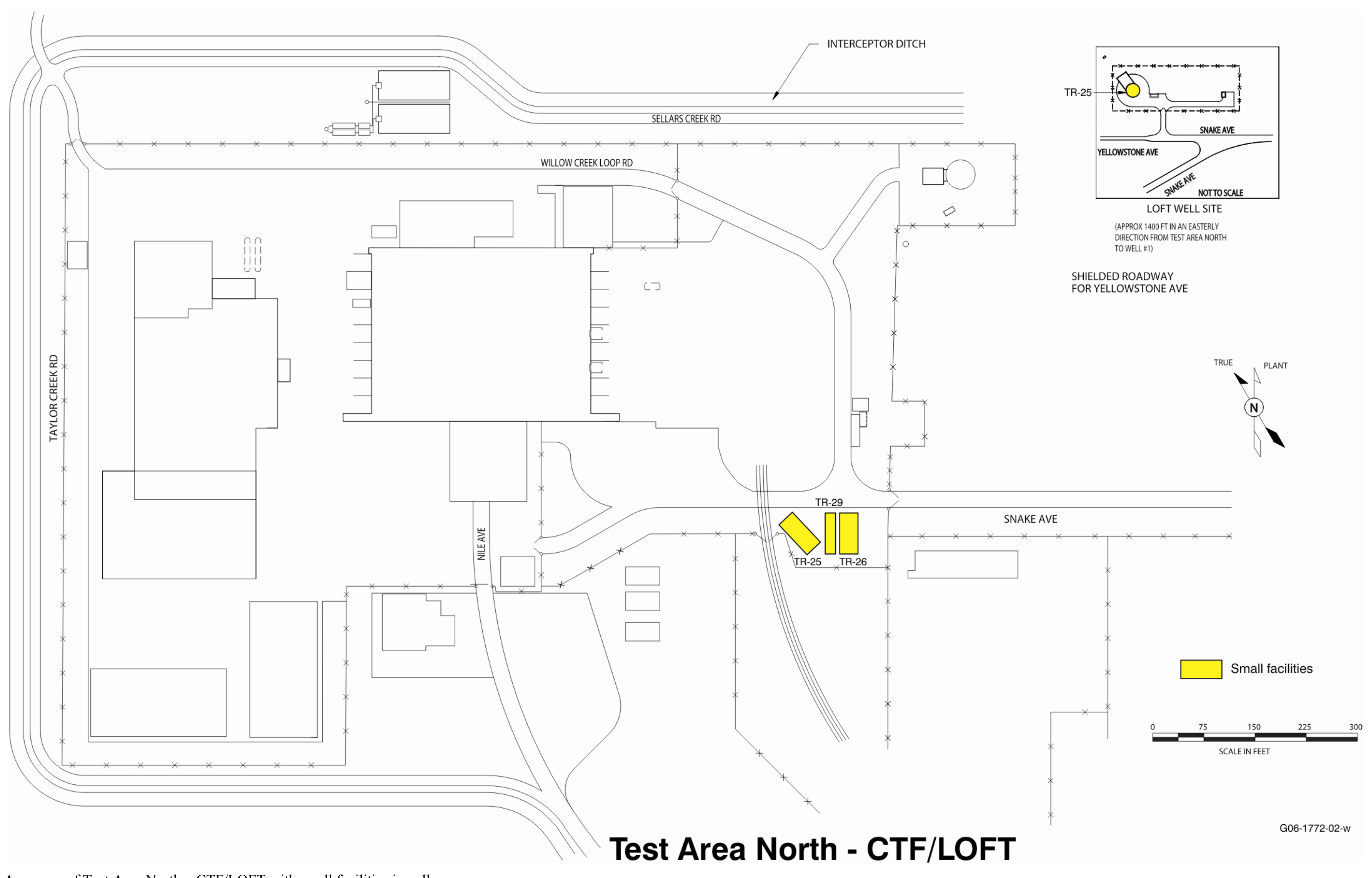




\subsection{Previous Closure/Cleanup Activities at the INL Site}

\subsubsection{Comprehensive Environmental Response, Compensation, and Liability Act Activities at the INL Site}

The INL Site was added to the EPA's National Priority List of hazardous substances contaminated sites on November 21, 1989 (CERCLIS Identification Number 4890008952). On December 9, 1991, DOE-ID entered into the FFA/CO (DOE-ID 1991) to address the remediation of contaminated areas. The FFA/CO divided the INL Site into 10 waste area groups (WAGs) corresponding to the major facilities and areas at the Site. Comprehensive Records of Decisions (RODs) have been signed for eight of the 10 WAGs. Remedial actions have been completed at WAGs 2, 4, 5, 6, 8, and 9. Remediation is ongoing at WAGs 3, 7, and 10. RODs are yet to be completed for Operable Units (OUs) 3-14, 7-13/14, and 10-08.

Remedial actions have addressed the cleanup of various contaminated soils sites across the INL Site. Remedial action upon contaminated soils and buried wastes continues at TAN, INTEC, RWMC, and other soil contamination sites within the INL Site but outside of the individual facility boundaries. Long-term monitoring and institutional controls are required for soil contamination sites where residual contamination remains in place. Long-term groundwater monitoring is also conducted pursuant to the FFA/CO, and groundwater remediation activities continue at TAN.

\subsubsection{Voluntary Consent Order Activities}

A Voluntary Consent Order (VCO) between DOE-ID and DEQ was signed on June 14, 2000 (DEQ 2000). The VCO addresses legacy hazardous waste compliance issues at the INL Site. Actions required by the VCO have been completed at CFA and PBF. VCO issues related to HWMA/RCRA tank systems at TAN, INTEC, and RTC are yet to be completed.

\section{THREAT TO PUBLIC HEALTH, WELFARE, AND/OR THE ENVIRONMENT}

The source of contamination at each of the buildings or structures addressed by this Action Memorandum depends on the specific operations conducted at the facility. In general, contamination at these facilities resulted from activities associated with research, testing, and processing of nuclear materials. Various resources were used to help identify the hazardous substances and nature and extent of contamination in the facilities. These resources included historical operations information, process knowledge, radiological survey reports, radiation occurrence reports, facility assessment reports, personnel interviews, facility characterization reports, vulnerability assessments, inspections, walkdowns, and knowledge of construction materials.

To the extent practicable, hazardous substances, including bulk chemicals that are no longer in use, have been, or will be, removed from the facilities during routine surveillance and monitoring (S\&M) activities. However, residual contamination may remain on facility surfaces, in piping and ductwork, and in structural materials.

In general, the primary radionuclide COCs are the following:

- Americium-241

- Cesium-137

- Cobalt-60 
- $\quad$ Strontium-90

- $\quad$ Plutonium isotopes

- $\quad$ Technetium-99

- $\quad$ Tritium

- Uranium isotopes.

At most of the buildings and structures, the activities of individual isotopes are not fully quantified but will be determined to support waste characterization. Additional radionuclides may be identified beyond the commonly encountered radionuclides listed above. In some cases, the data quality objectives process may be utilized to aid in characterization of the waste prior to disposal.

These buildings and structures also contain nonradioactive hazardous substances, as either contaminants from operations or components of structural materials. These include, but are not limited to, the following:

- Asbestos-containing material

- $\quad$ Cadmium

- $\quad$ Beryllium

- $\quad$ Lead

- $\quad \mathrm{PCBs}$

- $\quad$ Mercury

- $\quad$ Refrigerants

- Lubricants

- $\quad$ Solvents

- $\quad$ Corrosives

- $\quad$ High-efficiency particulate air (HEPA) filter media

- $\quad$ Sodium vapor and mercury vapor lighting.

At most of the buildings and structures, the activities/concentrations of individual hazardous substances are not yet fully identified but will be determined to support waste characterization. In some cases, the data quality objectives process may be utilized to aid in characterization of the waste prior to disposal. The buildings and structures addressed in this Action Memorandum may be contaminated with radioactive and/or nonradioactive hazardous substances. The risks associated with the radioactive and/or nonradioactive contaminants have not been quantified in detail. Consequently, only a qualitative discussion of the risks may be completed at this time.

The major COCs within the buildings and structures subject to this removal action are radionuclides, which are known carcinogens. While the levels of radioactive contamination in some of the buildings and structures may be significant, many of the facilities may have no contamination at all or have minor contamination on the surfaces or embedded in the structural material. As is typical with demolition of industrial structures, nonradiological hazardous substances, including asbestos insulation, heavy metals, and PCBs in building materials, are also present in the facilities. 
The "National Oil and Hazardous Substance Pollution Prevention Contingency Plan," 40 CFR 300.415(b)(2), establishes factors to be considered in determining the appropriateness of a removal action. Those factors include the following:

- Actual or potential exposure to nearby human populations, animals, or the food chain from hazardous substances or pollutants or contaminants

- Weather conditions that may cause hazardous substances or pollutants or contaminants to migrate or be released

- Hazardous substances or pollutants in drums, barrels, tanks, or other bulk storage containers that may pose a threat of release.

Conditions persist wherein threats to the public health or the environment exist. Hazardous substances, including radionuclides, are present or could be present within the equipment and structures. These substances pose an increasing threat of release to humans and ecological receptors as the facilities continue to deteriorate with age. Should contamination become exposed or structural integrity compromised, the potential increases for direct exposure of nearby personnel and the environment (i.e., inhalation of contaminated dust and debris, or direct contact with contaminated debris). The potential for exposure to the public through the airborne spread of radioactive contaminants would also increase. The potential for wind or precipitation-related releases of hazardous substances within the facilities also increases as the facilities continue to deteriorate with age. The external radiation, inhalation, and ingestion risks to the Site workers, the public, and ecological receptors associated with potential releases of contamination justify a non-time-critical removal action.

\section{ENDANGERMENT DETERMINATION}

Security controls, including administrative and physical access controls, are currently in place for the INL to limit unauthorized entrance. Only authorized personnel are allowed entry into areas where hazards exist. As long as DOE-ID retains control of these areas, these institutional controls would prevent direct contact with and exposure to the hazardous substances. However, institutional controls will not prevent deterioration of the facilities or eliminate the threat of release of radiological and hazardous substances to the environment. Radiological and hazardous substances could be released directly to the environment via a breach in a pipe, containment wall, roof, or other physical control as the facilities age and deteriorate. Radiological and hazardous substances could also be released to the environment through animal intrusion into contaminated structures and systems. Historically, intrusion and spread of contamination by rodents, insects, birds, and other organisms has been problematic.

As the facilities continue to age, the threat of substantial release of radiological and hazardous substances increases with time, and containing these materials and preventing them from being released to the environment becomes more difficult. The S\&M activities required to confine the hazardous substances may increase the risk of potential exposure to personnel. Comprehensive WAG RODs from these areas have demonstrated that historical releases from waste streams associated with these buildings and structures have presented an unacceptable risk to human health and the environment. In some cases, removal of these buildings and structures would accommodate access for remediation of these identified waste sites.

The potential exposure to workers and wildlife, the potential threat of future releases, the substantial risks associated with the radiological and hazardous substances at the facilities addressed by this Action Memorandum, and the risks associated with the waste sites beneath or adjacent to the facilities justify use of CERCLA removal action authority in accordance with Section 300.415(b)(2) of the 
"National Oil and Hazardous Substances Pollution Contingency Plan." Therefore, actual and/or threatened releases of hazardous substances from these facilities have the potential to present a threat to public health and/or the environment.

\subsection{Proposed Action}

The alternatives evaluated in the engineering evaluation/cost analysis are discussed in Section 4.3. The proposed removal action alternative is Alternative 2 (Removal and Disposal of Buildings, Structures, and Building Contents). When the decommissioning involves management and/or generation of wastes subject to regulation under the Idaho HWMA/RCRA, these wastes will be addressed pursuant to requirements of those regulations. The scope of Alternative 2 is intended to encompass remaining miscellaneous decommissioning actions under the ICP. The scope will further include decommissioning preparatory activities (for example, isolation of utilities, chemical removal, removal of piping and equipment) for the more substantial and significant facilities that will be subsequently addressed in future NTCRAs. This Action Memorandum excludes the end-state decisions for these more substantial or significant facilities and decisions regarding reactor vessel disposition and activities already identified under existing Action Memoranda or remedial actions pursuant to the FFA/CO. Building contents include, but are not limited to, structural materials, pumps, pipes, tanks, boilers, compressors, ductwork, electrical components, and other equipment. The types of wastes and debris likely to require disposal include, but are not limited to, solid waste, low-level radioactive waste, asbestos waste, and PCB-contaminated waste.

Wastes generated through implementation of Alternative 2 will be dispositioned at appropriate on-Site or off-Site waste disposal facilities, in accordance with the WAC of those facilities. For contaminated wastes generated during the decommissioning, the ICDF will be the preferred disposal location for wastes meeting the ICDF WAC. Demolition of buildings and structures will include removal of abovegrade structures. Belowgrade structures will be removed and disposed of in the same fashion as abovegrade buildings and structures. However, if belowgrade structures (including pipes and utility systems) are not contaminated or may be decontaminated to achieve RAOs and meet release criteria, they may optionally be left in place, backfilled, and brought to grade. Backfill will consist of clean fill materials and/or inert demolition waste from the abovegrade structures. If evidence of contamination to surrounding soils is encountered, those soils exceeding the RAOs may be excavated and disposed of at an appropriate on-Site or off-Site disposal facility in accordance with the WAC of the facility. Alternatively, if the soil contamination is extensive, or unusually complex, the site may be identified by DOE-ID as a new site under the FFA/CO, with concurrence by the DEQ and EPA.

\subsection{Removal Action Objectives}

The potential COCs that may be encountered during the decommissioning includes, but is not limited to, radionuclides, asbestos, heavy metals, and organic chemicals. General CERCLA protectiveness standards and RAOs are established in the individual WAG comprehensive RODs at INL. The comprehensive ROD for RWMC is pending. Completed comprehensive RODs where ICP decommissioning facilities will occur are available for TAN, RTC, INTEC, CFA, and the PBF. This section identifies the RAOs and goals for the activities associated with this NTCRA. Although general decommissioning of miscellaneous INL buildings and structures is not specifically addressed in the comprehensive WAG RODs, these RAOs are consistent with those established by the comprehensive WAG RODs. The relevant completed comprehensive WAG RODs are

- $\quad$ Final Record of Decision for Test Area North Operable Unit 1-10, DOE/ID-10682 (DOE-ID 1999a) 
- $\quad$ Final Record of Decision Test Reactor Area Operable Unit 2-13, DOE/ID-10586 (DOE-ID 1997) and Explanation of Significant Differences to the Record of Decision for Test Reactor Area Operable Unit 2-13, DOE/ID-10744 (DOE-ID 2000a)

- $\quad$ Final Record of Decision for the Idaho Nuclear Technology and Engineering Center, Operable Unit 3-13, DOE/ID-10660 (DOE-ID 1999b)

- $\quad$ Final Comprehensive Record of Decision for Central Facilities Area, Operable Unit 4-13, DOE/ID-10719 (DOE-ID 2000b)

- $\quad$ Record of Decision for Power Burst Facility and Auxiliary Reactor Area, Operable Unit 5-12, DOE/ID-10700 (DOE-ID 2000c).

The RAOs for this NTCRA are to perform the decommissioning of miscellaneous ICP buildings and structures consistent with the comprehensive WAGs RAOs to achieve the following:

- $\quad$ Prevent external exposure to COCs that would result in cumulative excess carcinogenic risks from multiple COCs to ensure risks remain less than 1 in 10,000 for a hypothetical resident 100 years in the future

- $\quad$ Prevent external exposure to COCs that would result in a hazard index greater than 1 for a hypothetical resident 100 years in the future

- $\quad$ Prevent future releases to the Snake River Plain Aquifer (SRPA) that would result in migration of contaminants to the aquifer such that Idaho groundwater quality standards may be exceeded and to ensure that cumulative excess carcinogenic risks due to groundwater ingestion from multiple COCs remain less than 1 in 10,000 for a hypothetical resident 100 years in the future

- $\quad$ Prevent unacceptable internal exposure to biota that would result in the lack of maintenance or recovery of healthy local populations/communities of ecological receptors that are or should be present at or near the site.

The removal action goals also are predicated on the current and future land uses established in the comprehensive WAG RODs, which generally include industrial land use until at least 2095 and the potential for residential land use thereafter. Actions conducted under this NTCRA will be reviewed with DEQ and EPA for continued protectiveness during the Sitewide CERCLA 5-year review process prescribed under the Federal Facility Agreement and Consent Order for the Idaho National Engineering Laboratory (DOE-ID 1991).

\subsection{Engineering Evaluation/Cost Analysis}

The Engineering Evaluation/Cost Analysis for General Decommissioning Activities under the Idaho Cleanup Project (DOE-ID 2006a) is available through the Administrative Record for the removal action and can be found at the following internet address: http://ar.inel.gov.

Three alternatives were considered for the general decommissioning activities to be performed under the ICP: (1) No Action; (2) Removal and Disposal of Buildings, Structures, and Building Contents; and (3) Continued Surveillance and Monitoring Followed by Future Decommissioning. Alternative 2 (Removal and Disposal of Buildings, Structures, and Building Contents) consists of decontamination and demolition of the facilities and associated waste disposal. Alternative 3 (Continued Surveillance and Monitoring Followed by Future Decommissioning) included a period of facility maintenance and 
monitoring to the year 2095, followed by deactivation, decontamination, and demolition. Alternative 3 (Continued Surveillance and Monitoring Followed by Future Decommissioning) would have only delayed the start of decommissioning and would have required expenditures for the continued surveillance and monitoring over the interim.

\subsubsection{Alternative 1-No Action}

Alternative 1 assumed all short-term and long-term maintenance of the facilities was terminated and the facilities locked to prevent entry. Alternative 1 would not have eliminated, reduced, or controlled risks to human health and the environment. DOE-ID is required by federal orders and state and federal laws to protect workers and the public from unacceptable exposures. Therefore, the INL currently has administrative and physical controls in place to prevent unacceptable exposures to ionizing radiation and other chemical hazards from contaminated materials. DOE-ID could not have implemented a no action alternative (i.e., no administrative or physical controls) because it would put workers at risk and would not meet the requirements of federal orders and state and federal laws. Therefore, the No Action alternative was not considered a viable alternative.

\subsubsection{Alternative 2-Removal and Disposal of Buildings, Structures, and Building Contents}

The scope of Alternative 2 is intended to encompass remaining miscellaneous decommissioning actions under the ICP. The scope will further include decommissioning preparatory activities (for example, isolation of utilities, chemical removal, removal of piping and equipment) for the more substantial and significant facilities that will be subsequently addressed in future NTCRAs. This Action

Memorandum excludes the end-state decisions for these more substantial or significant facilities and decisions regarding reactor vessel disposition and activities already identified under existing Action Memoranda or remedial actions pursuant to the FFA/CO. Building contents include, but are not limited to, structural materials, pumps, pipes, tanks, boilers, compressors, ductwork, electrical components, and other equipment. The types of wastes and debris likely to require disposal include, but are not limited to, solid waste, low-level radioactive waste, asbestos waste, and PCB-contaminated waste.

When the decommissioning involves management and/or generation of wastes subject to regulation under the Idaho HWMA/RCRA, these wastes will be addressed pursuant to requirements of those regulations. Wastes generated through implementation of Alternative 2 will be dispositioned at appropriate on-Site or off-Site waste disposal facilities, in accordance with the WAC of those facilities. For contaminated wastes generated during the decommissioning, the ICDF will be the preferred disposal location for wastes meeting the ICDF WAC. Demolition of buildings and structures will include removal of abovegrade structures. Belowgrade structures will be removed and disposed of in the same fashion as abovegrade buildings and structures. However, if belowgrade structures (including pipes and utility systems) are not contaminated or may be decontaminated to achieve RAOs and meet release criteria, they may optionally be left in place, backfilled, and brought to grade. Backfill will consist of clean fill materials and/or inert demolition waste from the abovegrade structures. If evidence of contamination to surrounding soils is encountered, those soils exceeding the RAOs will be excavated and disposed of at an appropriate on-Site or off-Site disposal facility in accordance with the WAC of the facility. Alternatively, if the soil contamination is extensive, or unusually complex, the site may be identified by DOE-ID as a new site under the FFA/CO, with concurrence by the DEQ and EPA. If a site is included under the FFA/CO, the site would be subject to further investigation and a subsequent response action as necessary under the FFA/CO. Alternative 2 is the selected alternative by this Action Memorandum. 


\subsubsection{Alternative 3-Continued Surveillance and Monitoring, Followed by Future Decommissioning}

Alternative 3 included a period of facility surveillance and monitoring to the year 2095, followed by deactivation, decontamination, and demolition. The year 2095 was used as the assumption for the period of continued S\&M, since the timeframe is established in the comprehensive WAG RODs, which include industrial land use until at least 2095 and the potential for residential land use thereafter. Alternative 3 would have only delayed the start of decommissioning and would have required expenditures for the continued surveillance and monitoring over the interim. The cost analysis only addressed the period of S\&M through 2095 and did not include the future costs of the eventual decommissioning itself.

\subsection{Compliance with Environmental Regulations, Including Those That Are Applicable or Relevant and Appropriate Requirements}

Section 121 of CERCLA (42 USC $\S 9621$ ) requires the responsible CERCLA implementing agency to ensure that the substantive standards of HWMA/RCRA and other applicable laws will be incorporated into the federal agency's design and operation of its long-term remedial actions and into its more immediate removal actions. DOE-ID is the implementing agency for this NTCRA. Both DEQ and EPA concur that an NTCRA is warranted to protect human health and the environment.

Table 2 lists the proposed ARARs that have been identified for this removal action. These ARARs are a compilation and expansion of the ARARs identified in the comprehensive WAG RODs. The ARARs list is based on several key assumptions:

- $\quad$ Any residual contamination left in place will meet the RAOs identified in Section 4.2.

- When the decommissioning involves management and/or generation of wastes subject to regulation under the Idaho HWMA/RCRA, these wastes would be addressed pursuant to requirements of those regulations.

- $\quad$ The majority of lead shielding will be removed from the buildings and structures subject to this Action Memorandum prior to initiation of the NTCRA through other regulatory activities intended to place the facilities in an environmentally safe condition. However, some lead may remain following these activities, which may require management under the scope of the NTCRA. Removed lead that constitutes hazardous waste and cannot be recycled or reclaimed shall be declared a hazardous waste or mixed low-level waste and will be disposed of at an off-Site disposal facility in accordance with the disposal facility WAC. Mercury located in mercury fluorescent lamps is planned for removal prior to this NTCRA under other regulatory activities intended to place the facility in an environmentally safe condition, as would the mercury-containing electrical switches and lights.

- Activities performed under the auspices of the VCO will be conducted outside the scope of the NTCRA.

- If decontamination liquids are generated, they will be disposed of at the ICDF evaporation ponds in accordance with the approved WAC. 
Table 2. Summary of applicable or relevant and appropriate requirements for the general decommissioning non-time-critical removal action.

\begin{tabular}{|c|c|c|}
\hline Requirement (Citation) & ARAR Type & Comments \\
\hline \multicolumn{3}{|l|}{ Clean Air Act and Idaho Air Regulations } \\
\hline “Toxic Substances,” IDAPA 58.01.01.161 & A & $\begin{array}{l}\text { Applies to any toxic substances emitting during implementation of the } \\
\text { removal action. }\end{array}$ \\
\hline$<10 \mathrm{mrem} / \mathrm{yr}, 40$ CFR 61.92, "Standard" & A & Applies to the waste-handling activities. \\
\hline "Emission Monitoring and Test Procedures," 40 CFR 61.93 & A & Applies to the waste-handling activities. \\
\hline "Compliance and Reporting," 40 CFR 61.94(a) & A & Applies to the waste-handling activities. \\
\hline $\begin{array}{l}\text { "Standard for Demolition and Renovation," and "Standard } \\
\text { for Waste Disposal for Manufacturing, Fabricating, } \\
\text { Demolition, Renovation, and Spraying Operations," } \\
40 \text { CFR } 61.145 \text { and .150 }\end{array}$ & $\mathrm{A}$ & $\begin{array}{l}\text { Applies to any asbestos-containing materials removed during the } \\
\text { decommissioning. }\end{array}$ \\
\hline $\begin{array}{l}\text { "Rules for Control of Fugitive Dust," and "General Rules," } \\
\text { IDAPA 58.01.01.650 and .651 }\end{array}$ & A & Applies to the waste-handling activities. \\
\hline \multicolumn{3}{|l|}{ Idaho Solid Waste Facilities Act } \\
\hline $\begin{array}{l}\text { "Applicable Requirements for Tier II Facilities," } \\
\text { IDAPA 58.01.06.012 }\end{array}$ & A & Applies to disposal of solid wastes at the TAN and CFA landfills. \\
\hline \multicolumn{3}{|l|}{ RCRA and Idaho Hazardous Waste Management Act } \\
\hline \multicolumn{3}{|l|}{ Generator Standards: } \\
\hline \multicolumn{3}{|c|}{ "Standards Applicable to Generators of Hazardous Waste," IDAPA 58.01.05.006, and the following, as cited in it: } \\
\hline "Hazardous Waste Determination," 40 CFR 262.11 & A & Applies to waste that will be generated during the removal action. \\
\hline \multicolumn{3}{|l|}{ General Facility Standards: } \\
\hline \multicolumn{3}{|c|}{$\begin{array}{l}\text { IDAPA 58.01.05.008, "Standards for Owners and Operators of Hazardous Waste Treatment, Storage, and Disposal Facilities," and the following, as } \\
\text { cited in it: }\end{array}$} \\
\hline “Temporary Units (TU)," 40 CFR 264.553 & A & $\begin{array}{l}\text { Waste may be treated or temporarily stored in a temporary unit prior to } \\
\text { disposal. }\end{array}$ \\
\hline "Staging Piles," 40 CFR 264.554 & $\mathrm{~A}$ & Waste may be temporarily staged prior to disposal. \\
\hline "General Inspection Requirements," 40 CFR 264.15 & A & $\begin{array}{l}\text { Applies to a facility staging, storing, or treating hazardous waste prior to } \\
\text { transfer to the ICDF or an off-Site facility. }\end{array}$ \\
\hline
\end{tabular}


Table 2. (continued).

\begin{tabular}{|c|c|c|}
\hline Requirement (Citation) & ARAR Type & Comments \\
\hline "Preparedness and Prevention," 40 CFR 264, Subpart C & A & $\begin{array}{l}\text { Applies to a facility staging, storing, or treating hazardous waste prior to } \\
\text { transfer to the ICDF or an off-Site facility. }\end{array}$ \\
\hline $\begin{array}{l}\text { "Contingency Plan and Emergency Procedures," } \\
40 \text { CFR 264, Subpart D }\end{array}$ & A & $\begin{array}{l}\text { Applies to a facility staging, storing, or treating hazardous waste prior to } \\
\text { transfer to the ICDF or an off-Site facility. }\end{array}$ \\
\hline $\begin{array}{l}\text { "Disposal or Decontamination of Equipment, Structures } \\
\text { and Soils," } 40 \text { CFR } 264.114\end{array}$ & A & $\begin{array}{l}\text { Applies to contaminated equipment used to remove, treat, or transport } \\
\text { hazardous waste. }\end{array}$ \\
\hline $\begin{array}{l}\text { "Use and Management of Containers," } \\
40 \text { CFR 264.171-178 }\end{array}$ & A & $\begin{array}{l}\text { Applies to containers used during the removal and treatment of hazardous } \\
\text { waste. }\end{array}$ \\
\hline \multicolumn{3}{|l|}{ Land Disposal Restrictions: } \\
\hline \multicolumn{3}{|c|}{ IDAPA 58.01.05.011, "Land Disposal Restrictions," and the following, as cited in it: } \\
\hline $\begin{array}{l}\text { "Applicability of Treatment Standards," } \\
40 \text { CFR 268.40(a)(b)(e) }\end{array}$ & A & $\begin{array}{l}\text { Applies to hazardous waste and secondary waste, if treatment is necessary } \\
\text { to meet the disposal facility's WAC or if treatment is required before } \\
\text { placement. }\end{array}$ \\
\hline $\begin{array}{l}\text { "Treatment Standards for Hazardous Debris," } \\
40 \text { CFR } 268.45\end{array}$ & A & $\begin{array}{l}\text { Applies to hazardous debris, if treatment is necessary to meet the disposal } \\
\text { facility's WAC or if treatment is required before placement. }\end{array}$ \\
\hline "Universal Treatment Standards," 40 CFR 268.48(a) & A & $\begin{array}{l}\text { Applies to nondebris hazardous waste and secondary waste, if treatment is } \\
\text { necessary to meet the disposal facility's WAC or if treatment is required } \\
\text { before placement. }\end{array}$ \\
\hline $\begin{array}{l}\text { "Alternative LDR Treatment Standards for Contaminated } \\
\text { Soil," } 40 \text { CFR } 268.49\end{array}$ & A & $\begin{array}{l}\text { Applies to contaminated soil, if treatment is necessary to meet the disposal } \\
\text { facility's WAC or if treatment is required before placement. }\end{array}$ \\
\hline \multicolumn{3}{|c|}{ IDAPA 58.01.05.016, "Standards for Universal Waste Management" } \\
\hline $\begin{array}{l}\text { "Standards for Large Quantity Handlers of Universal } \\
\text { Waste," } 40 \text { CFR 273, Subpart C }\end{array}$ & A & Applies to management of universal wastes. \\
\hline \multicolumn{3}{|l|}{ Idaho Groundwater Quality Rules } \\
\hline “Ground Water Quality Rule,” IDAPA 58.01.011 & A & $\begin{array}{l}\text { The waste-handling activities must prevent migration of contaminants from } \\
\text { the reactor complex that would cause the SRPA groundwater to exceed } \\
\text { applicable State of Idaho groundwater quality standards (same as maximum } \\
\text { contaminant levels) in } 2095 \text { and beyond. }\end{array}$ \\
\hline
\end{tabular}


Table 2. (continued).

\begin{tabular}{|c|c|c|}
\hline Requirement (Citation) & ARAR Type & Comments \\
\hline \multicolumn{3}{|l|}{ TSCA } \\
\hline $\begin{array}{l}\text { "Polychlorinated Biphenyls (PCBS) Manufacturing, } \\
\text { Processing, Distribution in Commerce, and Use Prohibitions," } \\
40 \text { CFR } 761\end{array}$ & A & $\begin{array}{l}\text { Applicable to removal, decontamination, storage, and disposal of items } \\
\text { (including equipment) with PCB contamination. }\end{array}$ \\
\hline \multicolumn{3}{|l|}{ To-Be-Considered Requirements } \\
\hline $\begin{array}{l}\text { "Radiation Protection of the Public and the Environment," } \\
\text { DOE Order } 5400.5 \text {, Chapter } \operatorname{II}(1)(a, b)\end{array}$ & TBC & $\begin{array}{l}\text { Applies to the decommissioning before, during, and after the removal } \\
\text { action. Substantive design and construction requirements will be met to } \\
\text { keep public exposures as low as reasonably achievable. }\end{array}$ \\
\hline “Radioactive Waste Management," DOE Order 435.1 & TBC & $\begin{array}{l}\text { Applies to the general decommissioning before, during, and after the } \\
\text { removal action. Substantive design and construction requirements will be } \\
\text { met to protect workers. }\end{array}$ \\
\hline $\begin{array}{l}\text { Region } 10 \text { Final Policy on the Use of Institutional Controls at } \\
\text { Federal Facilities (EPA 2006) }\end{array}$ & TBC & Applies to residual waste following completion of the removal action. \\
\hline \multicolumn{3}{|c|}{$\begin{array}{l}\text { ARAR = applicable or relevant and appropriate requirement. } \\
\text { CERCLA = Comprehensive Environmental Response, Compensation, and Liability Act. } \\
\text { CFR = Code of Federal Regulations. } \\
\text { DOE = Department of Energy. } \\
\text { EPA }=\text { Environmental Protection Agency. } \\
\text { ETR = Engineering Test Reactor. } \\
\text { ICDF = Idaho CERCLA Disposal Facility. } \\
\text { IDAPA = Idaho Administrative Procedures Act. } \\
\text { PCB = polychlorinated biphenyl. } \\
\text { RCRA = Resource Conservation and Recovery Act. } \\
\text { SRPA = Snake River Plain Aquifer. } \\
\text { TSCA = Toxic Substances Control Act. } \\
\text { WAC = waste acceptance criteria. }\end{array}$} \\
\hline
\end{tabular}


- $\quad$ Debris generated during demolition of the buildings and structures may have paint that contains PCBs. PCB-containing light ballasts will be disposed of at an appropriate disposal facility. If encountered, such waste may trigger substantive requirements of the Toxic Substances Control Act (15 USC $\S 2601$ et seq.). Lead-contaminated paint also may be removed, which would be subject to the requirements of RCRA hazardous waste regulations.

- Asbestos-containing material, which is both friable and nonfriable, will be encountered incidental to performance of the NTCRA. Friable or regulated asbestos-containing material is subject to specific asbestos regulations and will be acceptable for disposal at the ICDF and/or, if not radiologically contaminated, at the CFA Asbestos Landfill. Regulated asbestos will be removed and disposed of as required by 40 CFR 61.150, "Standard for Waste Disposal for Manufacturing, Fabricating, Demolition, Renovation, and Spraying Operations."

\subsection{Cultural Resources}

Section 106 of the National Historic Preservation Act of 1966 (NHPA) (16 USC $\S 470$ et seq.), as amended, requires agencies to consider the impact of undertakings on properties listed or eligible for listing in the National Register of Historic Places and to consult with the Idaho State Historic Preservation Officer (SHPO) and other interested parties when impacts are likely. It also requires federal agencies to invite the Advisory Council on Historic Preservation (ACHP) to participate in consultation when impacts may be adverse. The NHPA Section 106 process has been tailored to meet the unique needs of the INL Site. Section 110 of the NHPA directs federal agencies to establish programs to find, evaluate, and nominate eligible properties to the National Register of Historic Places, including previously unidentified historic properties that may be discovered during the implementation of a project (36 CFR 800). In addition, the Archaeological Resources Protection Act of 1979 (16 USC $\S 470 \mathrm{aa}-470 \mathrm{~mm}$ ), as amended, provides for the protection and management of archaeological resources on federal lands. Procedures and strategies to tailor these requirements to the unique needs of the INL Site are described in the Cultural Resource Management Plan (CRMP) (DOE-ID 2004). The CRMP is implemented through a Programmatic Agreement among DOE-ID, the Idaho SHPO, and the ACHP. Mitigation activities identified by the CRMP have been completed for the buildings and structures identified in Table 1 .

DOE is required to review as guidance the most current U.S. Fish and Wildlife Service list for threatened and endangered plant and animal species. DOE-ID determined that none of the alternatives would impact any threatened and endangered species and also determined that formal consultation with the U.S. Fish and Wildlife Service is not required for this action.

\subsection{Compliance with Disposal Facility Waste Acceptance Criteria}

Wastes generated through implementation of Alternative 2 will be dispositioned at appropriate on-Site or off-Site waste disposal facilities, in accordance with the WAC of those facilities. For uncontaminated solid wastes, the TAN Industrial Waste Landfill will be used for disposal of such wastes generated near TAN, and the CFA Industrial Waste Landfill will be utilized for those wastes generated elsewhere at the INL Site. For contaminated wastes generated during the decommissioning, the ICDF will be the preferred disposal location for wastes meeting the ICDF WAC.

The ICDF is a state-of-the art disposal facility designed and constructed with leachate collection and leak detection systems, with two 60-mil high-density polyethylene liners, and a 3-ft-thick clay bottom liner. The ICDF is an on-Site disposal facility that accepts CERCLA waste generated at the INL Site. Hazardous, mixed, low-level, asbestos, and Toxic Substances Control Act waste can be accepted for disposal at the ICDF (DOE-ID 2006b). Although the decommissioning to be performed under this 
NTCRA is not expected to generate any waste packages exceeding the Class C criteria established for wastes regulated by the Nuclear Regulatory Commission, if a waste package with activated metals does exceed the Class $\mathrm{C}$ criteria, a special performance assessment will be performed and reviewed by the regulatory agencies to ensure that there are no unacceptable risks associated with disposal at the ICDF.

\section{PROJECT SCHEDULE}

This removal action is expected to begin the general decommissioning activities upon issuance of this Action Memorandum. Decommissioning of buildings listed in Table 1 is expected to be completed by September 30, 2012. However, as discussed in Section 1, the intent of this Action Memorandum is to allow the addition, or deletion, of buildings and structures to the scope of the removal action, as appropriate, and with DEQ and EPA concurrence. Because of the possibility that the scope may expand to accommodate additional buildings and structures, the schedule for completion of the NTCRA will extend beyond 2012.

\section{PROJECT COST}

Cost estimates were prepared for the alternatives evaluated in the EE/CA (DOE-ID 2006a). The estimates were prepared in accordance with $A$ Guide to Developing and Documenting Cost Estimates During the Feasibility Study (EPA 2000). Costs were calculated for both capital expenditures and future operation and maintenance expenses. In accordance with EPA guidance, the cost for the alternatives over time was calculated as present net worth costs, which are sometimes referred to as net present value, to represent the costs in 2006 dollars.

Under the selected alternative, because the management of HWMA/RCRA hazardous wastes is not included in the scope of this NTCRA, disposal costs for these activities are not included in the cost estimates. The information in the cost estimate summary is based upon the best available information regarding the anticipated scope of the selected alternative. Changes in the cost elements are likely to occur as a result of new information and data collected during the engineering design and performance of the removal action. Major changes will be documented in the form of a memorandum placed into the Administrative Record file. This is an order-of-magnitude engineering cost estimate that is expected to be within +50 to $-30 \%$ of actual project cost. The present-worth cost estimate for the selected alternative is $\$ 41,193,000$ (see Table 3). The costs are based on present-day (2006) dollars.

Table 3. Present-worth cost estimate for the selected alternative, by area.

\begin{tabular}{ccccc}
\hline $\begin{array}{c}\text { TAN } \\
\text { (Present-Worth) }\end{array}$ & $\begin{array}{c}\text { RTC } \\
\text { (Present-Worth) }\end{array}$ & $\begin{array}{c}\text { INTEC } \\
\text { (Present-Worth) }\end{array}$ & $\begin{array}{c}\text { RWMC } \\
\text { (Present-Worth) }\end{array}$ & $\begin{array}{c}\text { Total } \\
\text { Present-Worth Cost }\end{array}$ \\
\hline$\$ 6,761,000$ & $\$ 18,115,000$ & $\$ 15,367,000$ & $\$ 9,035,000$ & $\$ 41,193,000$ \\
\hline
\end{tabular}

\section{EXPECTED CHANGE SHOULD ACTION BE DELAYED OR NOT TAKEN}

The expected change to the general decommissioning of miscellaneous INL buildings and structures should action be delayed, or not taken, would be that the facilities would remain under administrative and institutional control, as they are today. However, as the facilities continue to age, the threat of substantial release of radiological and hazardous substances increases with time, and containing these materials and preventing them from being released to the environment becomes more difficult. The S\&M activities required to confine the hazardous substances may increase the risk of potential exposure 
to personnel. If the action was delayed, continued expenditures for surveillance and maintenance costs would accrue during the time interval elapsed until final decommissioning activities are performed.

\section{STATUTORY AND REGULATORY AUTHORITY}

The proposed removal action is being undertaken by DOE-ID, as the lead agency, pursuant to CERCLA, Section 104(a), and Executive Order 12580, as recognized by Section 5.3 of the Federal Facility Agreement and Consent Order for the Idaho National Engineering Laboratory (DOE-ID 1991). In accordance with 40 CFR 300.415(j) and DOE guidance, on-Site removal actions conducted under the CERCLA are required to meet ARARs to the extent practicable considering the exigencies of the situation. The DOE-ID will comply with the ARARs and "to-be-considered" guidance as set forth in Section 4.4.

\section{OUTSTANDING POLICY ISSUES}

There are no outstanding policy issues.

\section{ENFORCEMENT}

DOE-ID is conducting this removal action as the lead agency under the authority of 40 CFR 300.5 , "Definitions," and 40 CFR 300.415(b)(1), "Removal Action."

\section{RECOMMENDATION}

This decision document represents the selected removal action alternative for implementation of general decommissioning activities under the Idaho Cleanup Project and was prepared in accordance with the Comprehensive Environmental Response, Compensation, and Liability Act (CERCLA) (42 USC $§ 9601$ et seq.), as amended by the "Superfund Amendments and Reauthorization Act of 1986" (Public Law 99-499). The conditions at the buildings and structures listed in Table 1 meet the criteria in 40 CFR 300.415(b)(2) of the "National Oil and Hazardous Substances Pollution Contingency Plan" (40 CFR 300). This decision is based upon the Administrative Record for the removal action.

The recommended action is to perform Alternative 2. The selected alternative meets the proposed RAOs regarding long-term risk, minimizes short-term worker risk and radiation exposure, is cost-effective, and provides a safe and stable configuration that is environmentally sound. DOE-ID also considers Alternative 2 consistent with the RAOs of the comprehensive WAG RODs and compliant with ARARs.

\section{PUBLIC PARTICIPATION}

The public participation period for the Engineering Evaluation/Cost Analysis for General Decommissioning Activities under the Idaho Cleanup Project (DOE-ID 2006a) was from September 9, 2006, through October 9, 2006. A public notice was sent to nine different Idaho and Wyoming newspapers on September 8, 2006. The notice was posted in the DOE Administrative Record electronically, and hard copies of the document were sent to the DOE Public Reading rooms in Idaho Falls and Boise. A presentation was provided to the INL Citizens Advisory Board on September 19, 2006, which was also open to participation from the general public. One letter regarding the EE/CA was received during the comment period and is included in Appendix A. 


\section{REFERENCES}

36 CFR 800, 2004, "Protection of Historic Properties," Code of Federal Regulations, Office of the Federal Register, August 2004.

40 CFR 61.92, 2006, "Standard," Code of Federal Regulations, Office of the Federal Register, July 2006.

40 CFR 61.93, 2006, "Emission Monitoring and Test Procedures," Code of Federal Regulations, Office of the Federal Register, July 2006.

40 CFR 61.94, 2006, "Compliance and Reporting," Code of Federal Regulations, Office of the Federal Register, July 2006.

40 CFR 61.145, 2006, "Standard for Demolition and Renovation," Code of Federal Regulations, Office of the Federal Register, July 2006.

40 CFR 61.150, 2006, "Standard for Waste Disposal for Manufacturing, Fabricating, Demolition, Renovation, and Spraying Operations," Code of Federal Regulations, Office of the Federal Register, July 2006.

40 CFR 262.11, 2006, "Hazardous Waste Determination," Code of Federal Regulations, Office of the Federal Register, July 2006.

40 CFR 264.15, 2006, "General Inspection Requirements," Code of Federal Regulations, Office of the Federal Register, July 2006.

40 CFR 264.114, 2006, "Disposal or Decontamination of Equipment, Structures and Soils," Code of Federal Regulations, Office of the Federal Register, July 2006.

40 CFR 264.171, 2006, "Condition of Containers," Code of Federal Regulations, Office of the Federal Register, July 2006.

40 CFR 264.172, 2006, "Compatibility of Waste with Containers," Code of Federal Regulations, Office of the Federal Register, July 2006.

40 CFR 264.173, 2006, "Management of Containers," Code of Federal Regulations, Office of the Federal Register, July 2006.

40 CFR 264.174, 2006, "Inspections," Code of Federal Regulations, Office of the Federal Register, July 2006.

40 CFR 264.175, 2006, "Containment," Code of Federal Regulations, Office of the Federal Register, July 2006.

40 CFR 264.176, 2006, "Special Requirements for Ignitable or Reactive Waste," Code of Federal Regulations, Office of the Federal Register, July 2006.

40 CFR 264.177, 2006, "Special Requirements for Incompatible Wastes," Code of Federal Regulations, Office of the Federal Register, July 2006. 
40 CFR 264.178, 2006, “Closure," Code of Federal Regulations, Office of the Federal Register, July 2006.

40 CFR 264.553, 2006, “Temporary Units (TU)," Code of Federal Regulations, Office of the Federal Register, July 2006.

40 CFR 264.554, 2006, "Staging Piles," Code of Federal Regulations, Office of the Federal Register, July 2006.

40 CFR 264, Subpart C, 2006, "Preparedness and Prevention," Code of Federal Regulations, Office of the Federal Register, July 2006.

40 CFR 264, Subpart D, 2006, "Contingency Plan and Emergency Procedures," Code of Federal Regulations, Office of the Federal Register, July 2006.

40 CFR 268.40, 2006, “Applicability of Treatment Standards," Code of Federal Regulations, Office of the Federal Register, July 2006.

40 CFR 268.45, 2006, “Treatment Standards for Hazardous Debris," Code of Federal Regulations, Office of the Federal Register, July 2006.

40 CFR 268.48, 2006, "Universal Treatment Standards," Code of Federal Regulations, Office of the Federal Register, July 2006.

40 CFR 268.49, 2006, “Alternative LDR Treatment Standards for Contaminated Soil," Code of Federal Regulations, Office of the Federal Register, July 2006.

40 CFR 273, Subpart C, 2006, "Standards for Large Quantity Handlers of Universal Waste," Code of Federal Regulations, Office of the Federal Register, July 2006.

40 CFR 300, 2006, "National Oil and Hazardous Substances Pollution Contingency Plan," Code of Federal Regulations, Office of the Federal Register, September 2006.

40 CFR 300.5, 2006, "Definitions," Code of Federal Regulations, Office of the Federal Register, September 2006.

40 CFR 300.415, 2006, "Removal Action," Code of Federal Regulations, Office of the Federal Register, September 2006.

40 CFR 761.79, 2006, "Decontamination Standards and Procedures," Code of Federal Regulations, Office of the Federal Register, June 2006.

15 USC $§ 2601$ et seq., 1976, “The Toxic Substances Control Act (TSCA) of 1976,” United States Code.

16 USC $\S 470$ et seq., 1966, "National Historic Preservation Act," United States Code, October 15, 1966.

16 USC § 470aa-470mm, 2002, “Archaeological Resources Protection Act," United States Code, January 22, 2002.

42 USC $\S 9601$ et seq., 1980, "Comprehensive Environmental Response, Compensation and Liability Act of 1980 (CERCLA/Superfund)," United States Code, December 11, 1980. 
42 USC § 9621, 1998, “Cleanup Standards,” United States Code, January 26, 1998.

DEQ, 2000, B. R. Monson, DEQ, to D. N. Rasch, DOE-ID, Enclosure: “Consent Order," Idaho Code $\S 39-4413$, June 14, 2000.

DOE O 435.1, 2001, "Radioactive Waste Management," Change 1, U.S. Department of Energy, August 28, 2001.

DOE O 5400.5, 1993, "Radiation Protection of the Public and the Environment," Change 2, U.S. Department of Energy, January 7, 1993.

DOE and EPA, 1995, Policy on Decommissioning of Department of Energy Facilities Under the Comprehensive Environmental Response, Compensation, and Liability Act (CERCLA), KLF-211-95, Rev. 0, U.S. Department of Energy, Washington, D.C., and U.S. Environmental Protection Agency, Washington, D.C., May 22, 1995.

DOE-ID, 1991, Federal Facility Agreement and Consent Order for the Idaho National Engineering Laboratory, Administrative Docket No. 1088-06-120, U.S. Department of Energy Idaho Operations Office; U.S. Environmental Protection Agency, Region 10; Idaho Department of Health and Welfare, December 9, 1991.

DOE-ID, 1997, Final Record of Decision Test Reactor Area Operable Unit 2-13, Idaho National Engineering and Environmental Laboratory, Idaho Falls, Idaho, DOE/ID-10586, U.S. Environmental Protection Agency, Idaho Department of Environmental Quality, U.S. Department of Energy Idaho Operations Office, December 1997.

DOE-ID, 1999a, Final Record of Decision for Test Area North Operable Unit 1-10 Idaho National Engineering and Environmental Laboratory, Idaho Falls, Idaho, DOE/ID-10682, Rev. 0, U.S. Environmental Protection Agency, Idaho Department of Environmental Quality, U.S. Department of Energy Idaho Operations Office, October 1999.

DOE-ID, 1999b, Final Record of Decision, Idaho Nuclear Technology and Engineering Center, Operable Unit 3-13, Idaho National Engineering and Environmental Laboratory, Idaho Falls, Idaho, DOE/ID-10660, Rev. 0, U.S. Environmental Protection Agency, Idaho Department of Environmental Quality, U.S. Department of Energy Idaho Operations Office, October 1999.

DOE-ID, 2000a, Explanation of Significant Differences to the Record of Decision for Test Reactor Area Operable Unit 2-13, DOE/ID-10744, Rev. 0, U.S. Environmental Protection Agency, Idaho Department of Environmental Quality, U.S. Department of Energy Idaho Operations Office, May 2000.

DOE-ID, 2000b, Final Comprehensive Record of Decision for Central Facilities Area, Operable Unit 4-13, DOE/ID-10719, Rev. 2, U.S. Environmental Protection Agency, Idaho Department of Environmental Quality, U.S. Department of Energy Idaho Operations Office, July 2000.

DOE-ID, 2000c, Record of Decision Power Burst Facility and Auxiliary Reactor Area, Operable Unit 5-12, Idaho National Engineering and Environmental Laboratory, Idaho Falls, Idaho, DOE/ID-10700, U.S. Environmental Protection Agency, Idaho Department of Environmental Quality, U.S. Department of Energy Idaho Operations Office, January 2000. 
DOE-ID, 2004, Idaho National Engineering and Environmental Laboratory Cultural Resource Management Plan, DOE/ID-10997, Rev. 0, U.S. Department of Energy Idaho Operations Office, August 2004.

DOE-ID, 2006a, Engineering Evaluation/Cost Analysis for General Decommissioning Activities under the Idaho Cleanup Project, DOE/ID-11291, Rev. 0, U.S. Department of Energy Idaho Operations Office, August 2006.

DOE-ID, 2006b, ICDF Complex Waste Acceptance Criteria, DOE/ID-10881, Rev. 3, U.S. Department of Energy Idaho Operations Office, October 2006.

DOE-NE-ID, 2005, Action Memorandum for Phase 1 of the Decommissioning of the Power Burst Facility Reactor Building (PER-620), DOE/NE-ID-11213, Rev. 0, U.S. Department of Energy Idaho Operations Office, February 2005.

EPA, 2000, A Guide to Developing and Documenting Cost Estimates During the Feasibility Study, EPA/540-R-00-002, U.S. Environmental Protection Agency, July 2000.

EPA, 2006, Region 10 Final Policy on the Use of Institutional Controls at Federal Facilities, U.S. Environmental Protection Agency, May 2006.

IDAPA 58.01.01.161, 1995, “Toxic Substances,” Idaho Administrative Procedures Act, Idaho Department of Environmental Quality, June 30, 1995.

IDAPA 58.01.01.650, 1994, "Rules for Control of Fugitive Dust," Idaho Administrative Procedures Act, Idaho Department of Environmental Quality, May 1, 1994.

IDAPA 58.01.01.651, 1994, "General Rules," Idaho Administrative Procedures Act, Idaho Department of Environmental Quality, May 1, 1994.

IDAPA 58.01.05.006, 2006, "Standards Applicable to Generators of Hazardous Waste," Idaho Administrative Procedures Act, Idaho Department of Environmental Quality, April 11, 2006.

IDAPA 58.01.05.008, 2006, "Standards for Owners and Operators of Hazardous Waste Treatment, Storage, and Disposal Facilities," Idaho Administrative Procedures Act, Idaho Department of Environmental Quality, April 11, 2006.

IDAPA 58.01.05.011, 2006, "Land Disposal Restrictions," Idaho Administrative Procedures Act, Idaho Department of Environmental Quality, April 11, 2006.

IDAPA 58.01.05.016, 2006, "Standards for Universal Waste Management," Idaho Administrative Procedures Act, Idaho Department of Environmental Quality, April 11, 2006.

IDAPA 58.01.06.012, 2003, “Applicable Requirements for Tier II Facilities,” Idaho Administrative Procedures Act, Idaho Department of Environmental Quality, April 3, 2003

IDAPA 58.01.011, 1997, “Ground Water Quality Rule,” Idaho Administrative Procedures Act, Idaho Department of Environmental Quality, March 20, 1997. 
Litus, M. and J. P. Shea, 2005, Summary of Cleanup at the Idaho National Laboratory Site, Idaho Completion Project, Idaho Falls, ID, ICP/EXT-05-00806, Rev. 0, Idaho Completion Project, Idaho National Laboratory, March 2005.

Public Law 99-499, 1986, "Superfund Amendments and Reauthorization Act of 1986 (SARA)," 100 Statutes 1728, Public Law, October 17, 1986. 
Appendix A

Public Comments Received during the Comment Period 


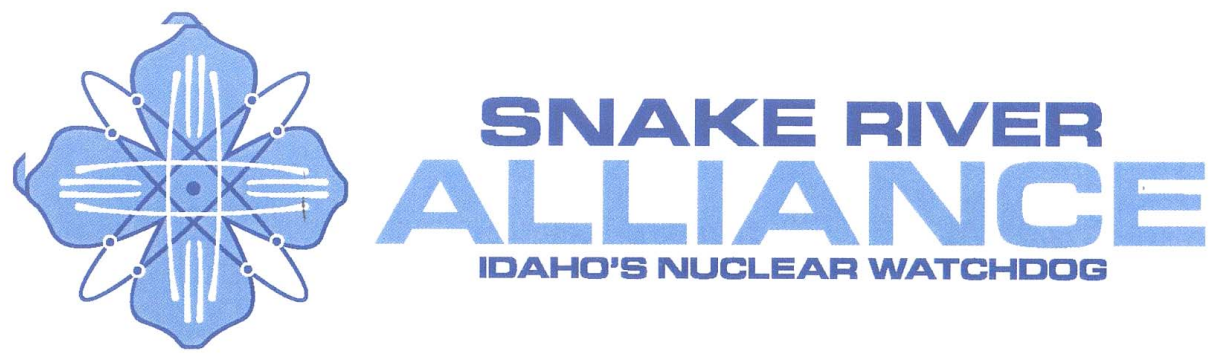

October 6, 2006

Nolan R. Jensen

Idaho Cleanup Project

DOE Idaho Operations Office, MS 1222

PO Box 1625

Idaho Falls, Idaho 83403-9987

Re: $\quad$ Comments on the Engineering Evaluation/Cost Analysis for General Decommissioning Activities Under the Idaho Cleanup Project

Dear Mr. Jensen:

The Snake River Alliance is an Idaho-based grassroots group working through research, education, and community advocacy for peace and justice, the end to nuclear weapons, responsible solutions to nuclear waste and contamination, and sustainable alternatives to nuclear power. I submit the following comments on the Engineering Evaluation/Cost Analysis for General Decommissioning Activities Under the Idaho Cleanup Project on behalf of our dues-paying members and board of directors.

The Snake River Alliance encourages efforts to cease use of the unlined pit at the Radioactive Waste Management Complex. Folding D\&D of the ancillary structures and some of the D\&D preparatory steps of the more significant structures into CERCLA is one such effort, and we support it. We're certain our current support will not be read as carte blanche for unrestricted future use of the INL CERCLA Disposal Facility. CERCLA coverage should also satisfy another goal: active stakeholder involvement. We encourage ICP personnel to use all CERCLA tools - and go beyond them when necessary - to ensure the public is informed about the ongoing activities discussed in this EE/CA. For instance, the public should be informed about the (perhaps series of) decisions regarding what steps ICP will take to ensure an appropriate mix of debris and non-debris waste at ICDF.

Even if the project does not encounter unexpected challenges, we expect full regulatory agency involvement.

We appreciate ICP's willingness to discuss this project with us. We look forward to the information we requested about void spaces at the open, unlined RWMC pit and any future subsidence they might cause.

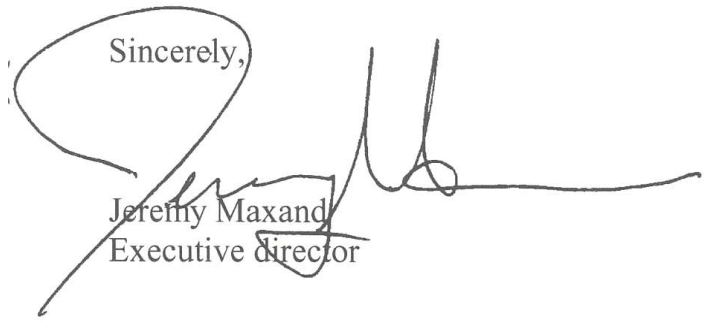

